2014

\title{
All His Sexless Patients: Persons with Mental Disabilities and the Competence to Have Sex
}

Michael L. Perlin

New York Law School, michael.perlin@nyls.edu

Alison Lynch

Follow this and additional works at: http://digitalcommons.nyls.edu/fac_articles_chapters

Part of the Health Law and Policy Commons, Law and Psychology Commons, Litigation Commons, and the Sexuality and the Law Commons

\section{Recommended Citation}

89 Wash. L. Rev. 257 (2014)

This Article is brought to you for free and open access by the Faculty Scholarship at DigitalCommons@NYLS. It has been accepted for inclusion in Articles \& Chapters by an authorized administrator of DigitalCommons@NYLS. 


\section{HEINONLINE}

Citation:

Michael L. Perlin; Alison J. Lynch, All His Sexless

Patients: Persons with Mental Disabilities and the

Competence to Have Sex, 89 Wash. L. Rev. 257, 300

(2014)

Provided by:

New York Law School<br>The Mendik Library

Content downloaded/printed from $\underline{\text { HeinOnline }}$

Sun Sep 24 20:51:03 2017

-- Your use of this HeinOnline PDF indicates your acceptance of HeinOnline's Terms and Conditions of the license agreement available at http://heinonline.org/HOL/License

-- The search text of this PDF is generated from uncorrected OCR text.

-- To obtain permission to use this article beyond the scope of your HeinOnline license, please use:

\section{Copyright Information}

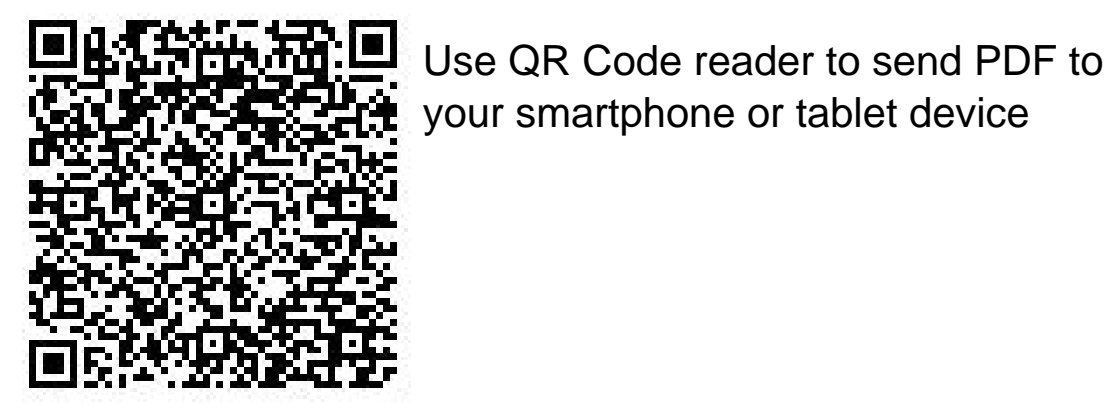




\title{
“ALL HIS SEXLESS PATIENTS": PERSONS WITH MENTAL DISABILITIES AND THE COMPETENCE TO HAVE SEX
}

\author{
Michael L. Perlin ${ }^{*} \&$ Alison J. Lynch ${ }^{* *}$
}

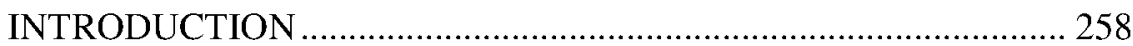

I. COMPETENCE TO HAVE SEX …........................................ 263

A. Factors to Consider in Assessing Competence to Have

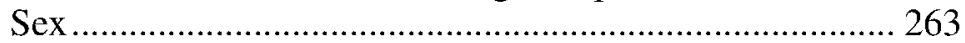

B. Defining "Sex" ............................................................ 265

1. Variations ............................................................. 266

a. Masturbation ........................................................ 267

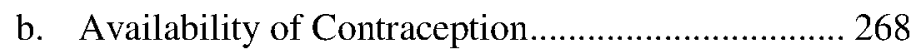

c. Gender Issues ................................................... 269

d. How This All Relates to Competency .................... 270

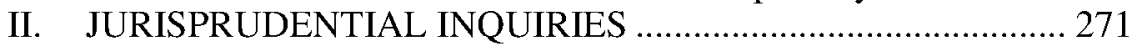

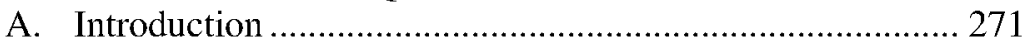

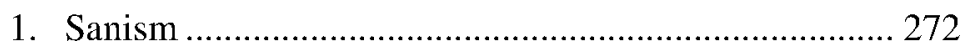

2. International Human Rights........................................ 273

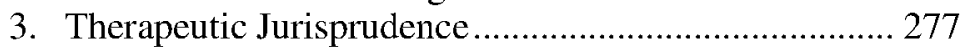

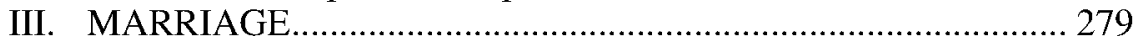

A. Mental Capacity to Marry ……......................................... 281

B. Context and Standing .................................................... 282

1. Spouse Seeks Annulment .......................................... 283

2. Guardian or Family Member Seeks Annulment

During Spouses' Lifetime...................................... 284

3. Guardian or Family Member Seeks Annulment After Death of a Spouse ..................................................... 286

4. "Heartbalm Actions" ............................................... 287

\footnotetext{
* Michael L. Perlin is a Professor of Law, Director of the International Mentality Disability Law Reform Project, and Director of the Online Mental Disability Law Program at New York Law School. The authors wish to thank Naomi Weinstein, Esq., and Jessica Cohn, Esq., for their invaluable help on earlier drafts of this Article. They are also grateful to Professor Heather Ellis Cucolo, for her helpful insights, especially with reference to issues related to prisoners and sex offenders. A portion of this Article was presented to the Rocky Mountain Psychological Association, Salt Lake City, Utah, April 2011. The authors have no financial interests that are the subject of this work or that influenced this work.

** Alison J. Lynch is a Staff Attorney at Disability Rights New York.
} 


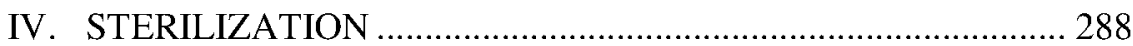

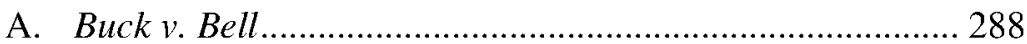

B. Misapplication of "Best Interests" Standard ..................... 289

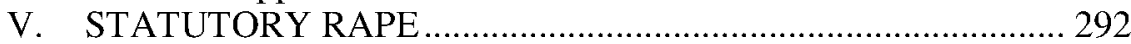

A. Statutory Law …............................................................... 292

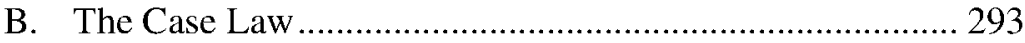

VI. OTHER APPROACHES: THE AMERICANS WITH

DISABILITIES ACT

CONCLUSION

\section{INTRODUCTION}

An article published in early 2014 in a peer-reviewed scientific journal began with a startling comment: "The recognition that individuals with disabilities have a desire for sexual relationships with other people is a relatively new concept in the scientific community."1 We believe that this observation-wildly at odds with much of the literature referred to in this Article and in another paper by the two authors ${ }^{2}$ - exemplifies the discussion in our previous paper about the confusion and misinformation that permeates all of disability law and policy, especially mental disability law. The baseline, rather, for any scholarly inquiry into this subject, must be that "[i]ndividuals [with disabilities] have the same needs for intimate relationships and sexual expression as everyone else." 3

With the growth in the field of mental disability law over the past forty years, very few topics involving persons with mental illness remain

1. Laura Gilmour, Veronica Smith \& Melike Schalomon, Sexuality and ASD: Current State of the Research, in 1 COMPREHENSIVE GUIDE TO AUTISM 569 (Vinood B. Patel et al. eds., 2014) (emphasis added). In this Article, we focus primarily - but not exclusively — on individuals with mental disabilities. Many other issues are raised in the context of individuals with physical disabilities. See, e.g., Julia Bahner, Legal Rights or Simply Wishes? The Struggle for Sexual Recognition of People with Physical Disabilities Using Personal Assistance in Sweden, 30 SEXUALITY \& DISABILITY 337, 347 (2012) (discussing "intimacy influenced activities" such as genital shaving). By way of example, there has been some preliminary exploration of the question of the impact of certain physical disabilities on a woman's ability to have orgasms. See, e.g., Clive Glass, Sexual Problems of Disabled Patients, 171 BRIT. MED. J. 107, 108-09 (1999).

2. See generally Michael L. Perlin \& Alison J. Lynch, "Love is Just a Four-Letter Word": Sexuality, International Human Rights and Therapeutic Jurisprudence, 1 CAN. J. COMP. \& CONTEMP. L. (forthcoming 2014).

3. Shirli Werner, Individuals with Intellectual Disabilities: A Review of the Literature on Decision-Making Since the Convention on the Rights of Persons with Disabilities (CRPD), 34 PUB. HeAlth REv. 1, 16 (2012). Professor Werner's focus was on persons with intellectual disabilities, but there is nothing in the literature that suggests persons with mental illness or psychosocial disabilities are any different in this regard. We use the phrase "mental disabilities" to encompass both groups. 
taboo or off limits to scholars and judges who face these issues daily. ${ }^{4}$ However, discussions of the question of whether persons with mental disabilities have a right to voluntary sexual interaction often touches a raw nerve in conversations about mental disability law-even with those who are practicing in the field. The discomfort that people feel in examining this topic is further exacerbated when discussing individuals who are institutionalized. Why is this? And what does this have to do with "sanism" - an irrational prejudice of the same quality and character as other irrational prejudices that cause, and are reflected in, prevailing social attitudes such as racism, sexism, homophobia, and ethnic bigotry ${ }^{5}$ that permeates all aspects of mental disability law and affects all participants in the mental disability law system: litigants, fact finders, counsel, and expert and lay witnesses? ${ }^{6}$ Consider this explanation as to how audience members responded to standard talks on this topic:

If as I saw it, sanist myths, based on stereotypes, are the result of rigid categorization and overgeneralization, then they function psychologically to "localize our anxiety, to prove to ourselves that what we fear does not lie within."7

We thus labeled individuals with mental illness as "deviant, morally weak, sexually uncontrollable [and] emotionally unstable." ${ }^{8}$ And often, we (especially professionals) regard them as not being human at all, and lacking human qualities including needs for affection and dignified ways of expressing affection. Our attitudes toward the sexuality of persons

4. This taboo even extends to the disability community. See Bahner, supra note 1 , at 338 .

5. The word "sanism" was, to the best of our knowledge, coined by Dr. Morton Birnbaum. See Morton Birnbaum, The Right to Treatment: Some Comments on Its Development, in MEDICAL, Moral AND Legal Issues IN Health CARE 97, 105 (Frank Ayd ed., 1974); see also Koe v. Califano, 573 F.2d 761, 764 n.12 (2d Cir. 1978). One of the authors has relied on the term constantly for the past twenty-five years to explain the roots of our attitudes towards persons with mental disabilities. See, e.g., Michael L. Perlin, "Half-Wracked Prejudice Leaped Forth": Sanism, Pretextuality, and Why and How Mental Disability Law Developed As It Did, 10 J. CONTEMP. LEGAL IsSUES 3 (1999) (discussing how sanism permeates all mental disability law). See infra text accompanying notes $61-68$.

6. On the way that sanism affects lawyers' representation of clients, see Michael L. Perlin, "You Have Discussed Lepers and Crooks": Sanism in Clinical Teaching, 9 CLINICAL L. REV. 683, 68990 (2003).

7. See Michael L. Perlin, "Limited in Sex, They Dare": Attitudes Toward Issues of Patient Sexuality, 26 AM. J. Forensic PSyChIATRY 25, 31 (2005) (quoting SANDER GILMAN, DIFFERENCE and Pathology: Stereotypes of Sexuality, RaCe, ANd Madness 240 (1985)). The audience members included some lay persons, but were mostly comprised of mental health professionals psychiatrists, psychologists, nurses-and personnel such as occupational therapists and physical therapists. Many of the responses to presentations discussed in this article were at hospital Grand Rounds talks.

8. Michael L. Perlin, On Sanism, 46 SMU L. REv. 373, 393 (1992). 
with mental disabilities reflect this labeling:

Society tends to infantilize the sexual urges, desires, and needs of the mentally disabled. Alternatively, they are regarded as possessing an animalistic hypersexuality, which warrants the imposition of special protections and limitations on their sexual behavior to stop them from acting on these "primitive" urges. By focusing on alleged "differentness," we deny their basic humanity and their shared physical, emotional, and spiritual needs. By asserting that theirs is a primitive morality, we allow ourselves to censor their feelings and their actions. By denying their ability to show love and affection, we justify this disparate treatment. $^{9}$

All these tensions are heightened in cases involving institutionalized persons, in which consumer desires and provider discomforts must be acknowledged and recalibrated. ${ }^{10}$ They must also be considered carefully in the context of Professor Suzanne Doyle's observation that sex is an "indeterminate and artificial" category defined "by people who want to preserve their own political and social advantages." 11

It is also telling as to how uncomfortable this topic makes many people when we consider the responses of audience members to frank discussions about these issues (at a talk in Florida, one attendee leapt to his feet to exclaim, "Professor Perlin, you are an agent of the devil!"); ${ }^{12}$ negative responses could be broken down into these categories:

1. Anger;

2. Denial;

3. Projection;

4. Transference;

9. Michael L. Perlin, Hospitalized Patients and the Right to Sexual Interaction: Beyond the Last Frontier?, 20 NYU REv. L. \& SoC. ChANGE 517, 537 (1993-94). For a subsequent consideration of the impact of this infantilization, see generally Janine Benedet \& Isabel Grant, Hearing the Sexual Assault Complaints of Women with Mental Disabilities: Evidentiary and Procedural Issues, 52 MCGILL L.J. 515 (2007).

10. See, e.g., Julie Tennille \& Eric Wright, Addressing the Intimacy Interests of People with Mental Health Conditions: Acknowledging Consumer Desires, Provider Discomforts, and System Denial, The Temple University Collaborative on Community Inclusion of Individuals with PSychiatric Disabilities 8 (Apr. 2013), http:/tucollaborative.org/pdfs/Toolkits Monographs_Guidebooks/relationships_family_friends_intimacy/intimacy.pdf. On the importance of intimacy to persons with disabilities, see Bahner, supra note 1, at 344-45.

11. Suzanne Doyle, The Notion of Consent to Sexual Activity for Persons with Mental Disabilities, 31 Liverpool L. REv. 111, 133 (2010) (citing Tobin SEBERs, DisAbIlity Theory 73 (1998)).

12. Perlin, supra note 7 , at 35 . On how inquiries in this area have traditionally been "blocked," see David John Frank \& Nolan Edward Phillips, Sex Laws and Sexuality Rights in Comparative and Global Perspectives, 9 ANN. REV. L. \& SOC. SCI. 249, 250 (2013). 
5. Fear;

6. Religiosity. $^{13}$

Audience responses-whether the audiences were composed of lawyers, physicians, mental health professionals, advocates, family members or lay persons - have been similar in other nations, both common law (the United Kingdom) and civil law (Japan). ${ }^{14}$ Again, these attitudes deny the empirical realities to which we have referred. ${ }^{15}$

Although this often appears to be a difficult subject to raise, even among those familiar and comfortable with other aspects of mental disability, it is one that must be raised. Dignity concerns and rights violations will occur if there is not a full understanding of the importance of the ability for persons with mental illness to practice free sexual expression. There has been some literature that begins to discuss this and to delve into the intricacies of the subject. However, we believe that much of this literature presumes that the "subjects" of these papers - those with mental illness who are institutionalized-are incompetent. The discussions therefore only address ability to engage in sexual activities from the perspective of an incompetent, institutionalized adult. We hope to broaden the scope of these examinations, and rather than presume incompetency, deal directly with the very likely situation of a competent, mentally ill person wishing to engage in sexual activity. We hope to examine legal competency, as well as the difficulties encountered when one begins to use different measures of "competency" for different tasks or activities. We will also explore

13. Perlin, supra note 7, at 34-35. Eddie McCann has speculated that this may be because of a fear that simply addressing this issue "will be seen as actively encouraging widespread institutional promiscuity." Eddie McCann, The Expression of Sexuality in Persons with Psychosis: Breaking the Taboos, 32 J. ADVANCED NuRSING 132, 133 (2000).

14. For attitudes in Asia, see generally Michael L. Perlin, "Everybody Is Making Love/Or Else Expecting Rain": Considering the Sexual Autonomy Rights of Persons Institutionalized Because of Mental Disability in Forensic Hospitals and in Asia, 83 WASH. L. REV. 481 (2008). In a subsequent paper, the authors will explore the cognitive dissonance in the laws of Asian nations that demonstrate "how complicated and messy it can be for a foreign law from the distant past to be brought into congruence with contemporary and evolving societal norms." See George Baylon Radics, Decolonizing Singapore's Sex Laws: Tracing Section 377 a of Singapore's Penal Code, 45 CoLUM. HUM. RTS. L. REV. 57, 99 (2013) (considering the parallel question of the current status of Singapore's criminalization of consensual sodomy). On comparative perspectives in general, see Frank \& Phillips, supra note 12.

15. See Werner, supra note 3, at 16 (citing Mona Eklund \& Margareta Ostman, Belonging and Doing: Important Factors for Satisfaction with Sexual Relations as Perceived by People with Persistent Mental Illness, 56 INT'L J. SoC. PSyCHIATRY 336 (2010)); Martin Lyden, Assessment of Sexual Consent Capacity, 25 Sexuality \& Disability 3 (2007); Eileen Dukes \& Brian E. McGuire, Enhancing Capacity to Make Sexuality-Related Decisions in People with an Intellectual Disability, 53 J. INTELLECTUAL \& DISABILITY RES. 727 (2009). 
the attitudes that surround this type of discourse, and their impact on advancing the rights of persons with mental illness.

In this Article, we consider these attitudes while seeking to answer the following questions:

- In this area of law and policy, is there any unitary definition of competence?

- Are there certain factors that must be considered in determining "sexual competence"?

- How does domestic law and policy relate to issues of sexual competence, and does it impact how we should approach these issues?

- What are the international human rights law and therapeutic jurisprudence implications of the answers to these questions?

In Part I, we will discuss competence to engage in sexual activity in matters involving persons with mental disabilities, looking also at the question of what we mean when we refer to "sex." We then consider in Part II the significance of sanism, the potential implications of international human rights law, and the meaning of therapeutic jurisprudence to this inquiry. Then, in Part III, we will discuss issues of competency in the context of marriage and, briefly, in the context of sterilization. In Part IV, we will look at competency in the context of criminal law, focusing mostly on the ways that "statutory rape" is defined in cases with putatively consensual sex involving persons with mental disabilities. We will examine in Part $\mathrm{V}$ the maturation of the Americans with Disabilities Act as a litigation tool. We will then conclude with a few thoughts and recommendations.

Our title comes, in part, from Bob Dylan's magnificent song, Desolation Row (from the line: "But all his sexless patients/They're trying to blow it up"). ${ }^{16}$ The music and social critic Mike Marqusee characterizes Desolation Row as "a brutal vision of persecution in which social control is depicted as a form of torture." ${ }^{17}$ We exercise such "social control" over those institutionalized because of mental disability, and we ultimately can see that the suppression of all sexual desire and action is, in fact, a form of social torture.

16. Bob Dylan, Desolation Row, BOBDYLAN.COM, http://www.bobdylan.com/us/songs/ desolation-row (last visited May 5, 2014).

17. Mike Marqusee, Chimes of Freedom: The Politics of Bob Dylan's Art 192 (2003). 


\section{COMPETENCE TO HAVE SEX}

\section{A. Factors to Consider in Assessing Competence to Have Sex}

We must start with the assumption that all individuals have the capacity to consent to sexual relations, and that the presence of a mental disorder, in itself, does not mean that the individual lacks this capacity. ${ }^{18}$ With this as a "given," for the purposes of this article, it is first necessary to unpack the different modes of analysis to be engaged in determining capacity and competency, and understanding the important distinctions between the two concepts. Capacity "refers to an individual's actual ability to understand, appreciate, and form a relatively rational intention with regard to some act." ${ }^{19}$ Competency is a legal assessment that varies based on the act or decision making that is being considered. ${ }^{20}$ Most famously, in Godinez v. Moran ${ }^{21}$ the Supreme Court imposed a unitary standard of competency in criminal cases, ${ }^{22}$ holding the competency to waive counsel or to plead guilty was to be assessed by the same standard as competency to stand trial. ${ }^{23}$ Justice Harry Blackmun in dissenting noted archly, "A person who is 'competent' to play basketball is not thereby 'competent' to play the violin ... Competency for one purpose does not necessarily translate to competency for another purpose." 24

18. See Mental Welfare Commission of Scotland, Consenting Adults? Guidance For Professionals aNd CAREERS WHEN CONSIDERING Rights AND Risks IN SEXUAL RELATIONSHIPS INVOLVING PEOPLE with A MENTAL DisORDER 4 (2007). See generally Elizabeth Ford, Michele Rosenberg, Margarita Holsten \& Tyson Boudreaux, Managing Sexual Behavior on Adult Acute Care Inpatient Psychiatric Units, 54 PSYCHIATRIC SERVICEs 346 (2003).

19. Steven B. Bisbing, Competency and Capacity: A Primer, in Legal Medicine 325, 325 (Shafeek S. Sanbar ed., 7th ed. 2007). On why inquiries into capacity are an insufficient basis for decision-making about persons with mental disabilities engaging in sexual interactions, see Andreas Dimopoulos, Let's Misbehave: Intellectual Disability and Capacity to Consent to Sex 1 (Sept. 1, 2012) (unpublished paper presented to Society of Legal Scholars), available at http://papers.ssm.com/sol3/papers.cfm?abstract_id=2332259.

20. See generally Michael L. Perlin et al., Competence n the Law: From Legal Theory to CLINICAL APPLICATION (2008).

21. 509 U.S. 389 (1993). The Supreme Court subsequently backed off of the rigidity of the Godinez holding in Indiana v. Edwards, 554 U.S. 164 (2008). The Court there held that the right of self-representation was not absolute and the State could insist that an attorney be appointed to represent a mentally ill defendant even though he had been found competent to stand trial. Id. at $171,178$.

22. Godinez, 509 U.S. at 402 .

23. Id. at 391 .

24. Id. at 413 (Blackmun, J., dissenting). On the need to consider competencies in matters of sexuality as a distinct area of inquiry, see Oana Georgiana Girlescu, Sexuality and Disability: An Assessment of Practices under the Convention for the Rights of Persons with Disabilities 64 (2012) (unpublished thesis, Central European University), available at http://www.etd.ceu.hu/2013/ 
Both of these concepts are intertwined in assessing the extent to which a person can exercise informed consent. In the context of this Article, such consent encompasses:

- An individual's ability to understand the sexual nature of an act, and to understand that participation in such an act must be voluntary;

- An individual's understanding of the potential consequences and implications of the decision to engage in a sexual act; and

- An individual's ability to communicate a decision as to whether he or she wishes to engage in such an activity. ${ }^{25}$

There is also the difficulty of establishing "clinical" competency, for those persons who are institutionalized. There is no standard that clinicians can apply when determining competency; in fact, it is a very fluid determination. In a survey of institutions' views on their ability to handle ethical concerns of patient sexual expression, author Eric Wright found, "aside from formal legal declarations of incompetence, establishing competence to engage in sexual activity during treatment is further complicated by the dynamic nature of psychiatric symptoms, variation in patients' sexuality-related knowledge and experience, and institutional policies." ${ }^{26}$ Moreover, in certain locations, the relationship between sexuality and privacy" is "directly related to assessments about ... competence." 28

The reality is, however, that we too often fail to take any of this into account and instead superimpose a societal presumption of incompetency ${ }^{29}-\mathrm{a}$ "damaging message[]" when applied to any aspects

girlescu_oana.pdf.

25. Doyle, supra note 11, at 117-18; see also Martin Lyden, Assessment of Sexual Consent Capacity, 25 SeXuality \& Disability 3 (2007); Paul Abramson et al., Consenting to Sex and Severe Mental Illness: Terra Incognita and a Priest with AIDS, 30 SEXUALITY \& DISABILITY 357, 363 (2012).

26. Eric R. Wright, Institutional Capacity to Respond to the Ethical Challenges of Patient Sexual Expression in State Psychiatric Hospitals in the United States, 7 J. Ethics Mental Health 1, 2 (2012). For a consideration of how institutional living inevitably shapes policies related to masturbation, see generally infra text accompanying notes 39-44. See also Michael Gill, Sex Can Wait, Masturbate: The Politics of Masturbation, 15 SEXUALITIES 472 (2012).

27. See infra text accompanying note 41 .

28. Gill, supra note 26 , at 476 .

29. On similar incorrect presumptions of incompetency in the law, see, for example, Hillary Rodham (Clinton), Children Under the Law, 43 HARV. EDUC. REv. 487, 506 (1973) (presumed incompetency in children); Lauren Sudeall Lucas, A Dilemma of Doctrinal Design: Rights, Identity and the Work-Family Conflict, 8 FLA. INT'L UNIV. L. REV. 379, 386 (2013) (presumed physical incompetency of pregnant teachers). On how lawyers often impermissibly engage in such a presumption of incompetency with regard to their institutionalized clients, see Michael L. Perlin, "I Might Need a Good Lawyer, Could Be Your Funeral, My Trial": A Global Perspective on the Right 
of a person with a mental disability. ${ }^{30}$ This, more than anything else, leads to the confusion, dissonance, and tension in this area of law, society, and personhood.

\section{B. Defining "Sex"}

In an earlier article, one of the authors considered the difficulties in defining what we mean by "sex": 31

Finally, we must consider whether any of [our] answers depends upon our definition of sex. Do we need to consider every possible permutation of sexual behavior? Does it make a difference if we are discussing monogamous heterosexual sex, polygamous heterosexual sex, monogamous homosexual sex, polygamous homosexual sex, or bisexual sex? Does sex mean intercourse? What about oral sex? Anal sex? Masturbation? Voyeurism? Exhibitionism? Should erotic or pornographic material be made available to patients? If so, what sortsmagazines of the kind often available at convenience stores or "hard core" magazines"? What about sexually explicit literature that might appear to involve, condone, or encourage violence? Should sexually explicit videos or movies be available for patients to see? If so, should they view them communally or individually? What if a patient's prehospitalization behavior involved significant "sexual acting out" in what had been seen as inappropriate ways? Should a patient's decision to engage in what is sometimes perceived as "deviant" sexual behavior subsequently be used as evidence of their danger either to self or others or of "grave disability"? ${ }^{32}$

Defining "sex" is made more complex because, on many levels, sexuality is "an identity rather than [simply] an act." 33 The identity,

to Counsel in Civil Commitment Cases, and Its Implications for Clinical Legal Education, 28 WASH. U. J.L. \& POL'Y 241, 262 (2008). There is no question that not even a judgment of involuntary commitment acts as an adjudication of incompetency. See, e.g., N.J. STAT. ANN. § 30:4-24.2(c) (West 2013).

30. Eli Best, Atypical Actors and Tort Law's Expressive Function, 96 MARQ. L. REV. 461, 488 (2012).

31. Sexuality must be defined "as wider than just physical function"; this is "particularly important for persons with disabilities." Glass, supra note 1, at 518 .

32. Perlin, supra note 9, at 527. See generally Michael L. Commons, Judi T. Bohn, Lisa T. Godon, Mark J. Hauser \& Thomas G. Gutheil, Professionals' Attitudes Towards Sex Between Institutionalized Patients, 46 AM. J. PSYCHOTHERAPY 571 (1992) (discussing ways that mental health professionals' attitudes towards sex are influenced by the nature of the sexual activity and the patients' sexual orientation).

33. Frank \& Phillips, supra note 12, at 252. 
which also allows for group membership based on certain preferences, is yet another way of distancing those with mental illnesses from society in general, where there may be taboos but no complete disallowance of certain sexual behaviors. People with mental illnesses may be told, directly or indirectly, that their sexual behavior is abnormal or unacceptable, especially if those persons are institutionalized. This becomes all the more critical of an issue when we acknowledge the reality that masturbation, by way of example, is often treated in institutions as a behavioral infraction. ${ }^{34}$ Again, this message to persons with mental illness that their sexual activities are in some way inappropriate is exacerbated by the omnipresence of false, stereotypical beliefs, such as, for example, "people with schizophrenia 'don't do sex.", 35

\section{Variations $^{36}$}

Different sexual preferences are common enough among those not diagnosed with a mental illness, and while certain prejudices exist against particular subcultures that promote a particular sexual activity, there continue to be many ways of expressing an individual's natural sexual preferences without facing discrimination or disgust. ${ }^{37}$ However, in the literature dealing with a mentally ill individual's right to engage in sex, the word "sex" is generally used broadly, without much thought as to what exactly it is encompassing. We believe it is important to begin naming and discussing some of the sexual practices that, while not "vanilla" or "mainstream," are likely to be sought by those with mental disabilities. ${ }^{38}$

34. Gill, supra note 26, at 479. Professor Gill also speculates that the association between masturbation and pornography is one reason why there is so little public discussion about masturbation. Id. at $490 \mathrm{n} .10$.

35. McCann, supra note 13 , at 133.

36. On the social and cultural factors that surround all aspects of sexuality, see Bahner, supra note 1, at 350-51: "[C]ultural sexual scripts influence not only the sexual acts per se but also many surrounding factors that may be needed in order to be able to reach desired sexual goals." There are other variations, of course, that we do not address here (e.g., group sex, "rough" sex, phone sex). We plan to discuss these in a future article.

37. See id. at 337.

38. See id. at 340 ("[T]he heterosexual, non-disabled monogamous couple, belonging to the same generation, having "vanilla sex' in their home is still considered the norm."). See generally Gayle Rubin, Thinking Sex: Notes for a Radical Theory of the Politics of Sexuality, in CULTURE, SOCIETY AND SEXUAlity: A READER 150 (Richard Parker \& Peter Aggleton eds., 1984). 


\section{a. Masturbation $^{39}$}

Although sexual activity often refers to intercourse where two people are involved, one variation of sexual activity is masturbation. While not often discussed publicly, society seems to generally accept that people masturbate, and it does not have the same kind of taboos associated with it as other, less mainstream kinds of sexual acts. In fact, masturbation training in sex education "represents one of the few sanctioned approaches for individuals with intellectual disabilities." 40

If masturbation is viewed as an appropriate practice, institutions must be prepared to create safe spaces for patients, just as a noninstitutionalized person would be able find his or her own space, to privately engage in masturbation. If one is in a facility that denies privacy, where can one masturbate in a "safe place"? ? $^{41}$ Although sexual behaviors of all sorts are seen generally as private matters, it becomes a public issue within the context of institutionalization. ${ }^{42}$ All of this, though, is always shrouded in secrecy. As Professor Gill notes, "[t]he masturbatory closet remains shut." 43

Beyond allowing masturbation for patients who are institutionalized, there is also a benefit to engaging in masturbation training, particularly with individuals who may need sexual health education. Siebers has listed four benefits of masturbation training:

(1) to help patients with mental disabilities understand that sexual acts should be private, allowing authorities to eliminate offensive behavior from public spaces; (2) [t]o provide patients with a means of releasing tension and controlling frustration, creating a more passive and manageable population for caregivers; (3) [t]o teach safer methods of masturbation to patients who are injuring themselves in the pursuit of sexual pleasure; and (4) to introduce the pleasures of sexuality as part of typical human existence to people for whom these pleasures are unknown. ${ }^{44}$

Siebers recognizes the therapeutic value of this practice, which is an

39. See generally Gill, supra note 26, at 477 ("The meaning behind masturbation fluctuates based on historical situations.").

40. Id. at 472 .

41. See generally Gill, supra note 26.

42. Id. at 480 (citing Deanna McGaughey \& Richard Tewksbury, Masturbation, in PRISON SEX: Practice AND Policy 133, 135 (Christopher Hensley ed., 2002))

43. Id. at 477 (citations omitted).

44. SIEBERS, supra note 11 , at 162 (quoting Gill, supra note 26 , at 484). 
important consideration. ${ }^{45}$ Not only does this training teach appropriate behaviors, but it also allows for therapeutic "release" of urges or frustrations in a safe way, something that otherwise may never be discussed with these patients.

An extraordinarily controversial question is the appropriateness of using care workers as sexual surrogates in cases involving persons with disabilities. ${ }^{46}$ Such surrogacy can involve masturbation or intercourse. ${ }^{47}$ Several European nations-including the Netherlands, Germany, Denmark and Switzerland-allow "limited 'touching' services for [persons with severe disabilities] through non-profit organisations." ${ }^{48}$ In fact, in Denmark, it is the care worker's duty to facilitate service users' sexuality, whether it concerns assistance in order to have sex with a partner, to masturbate, or to contact a prostitute. ${ }^{49}$

\section{b. Availability of Contraception}

Another issue that must be addressed is the availability of contraception for male and female patients. As discussed further below, the notion of sexuality is quite gendered, and the same may be true of access to contraceptives. Would it be reasonable to provide condoms to men and women? Or birth control? Would there ever exist a justification for providing one, but not the other? ${ }^{50}$

Eric Wright's study of psychiatric hospitals' policies regarding patient sexuality found that "only a minority of the [psychiatric institutions surveyed] had established guidance regarding 'reproductive health and behavior (pregnancies, abortion rights, access to birth control, etc.)","51 Formal policies can help to ensure that facilities respect the sexual autonomy of their residents and have a protocol for maintaining patient health and safety.

\footnotetext{
45. See id. at $162-63$.

46. See Perlin \& Lynch, supra note 2, at 12-14.

47. See generally Touching BASE INC., http://www.touchingbase.org/ (last visited Apr. 17, 2014).

48. Jacob Appel, Sex Rights for the Disabled?, 36 J. MED. ETHICS 152, 153 (2010).

49. Bahner, supra note 1 , at 339.

50. In at least one New York City hospital, male patients leaving the facility on unsupervised community leave are given condoms upon request. Female patients, on the other hand, must have their competency (informally) assessed before birth control pills can be prescribed. See Perlin, supra note 9 , at 541 .
}

51. Wright, supra note 26 , at 3. 


\section{c. Gender Issues}

A person's sexuality is often entwined with his or her gender identity. This can result in different treatment based on that identity. Issues of men's and women's sexuality are viewed differently by society, especially with regard to the sexual needs of both genders. ${ }^{52}$ With the addition of a mental disability, these issues become even more difficult to contend with.

The types of sexual activities we have discussed above demonstrate some of the gender disparities of our society that have also become obvious in issues of sexual activity. Masturbation, for example, is generally viewed as an activity which men engage in more frequently than women, with the thought process of many being that men somehow "need" to engage in masturbation, while women choose to without the same need. ${ }^{53}$

Sexual surrogacy is another instance where gender stereotypes play out. The basic stereotype of men somehow needing sex, or needing to orgasm, where women only enjoy it but have no greater physiological need is apparent in current surrogate situations. Japan's White Hands, for example, provide a service that allows only men to be masturbated. When asked about the viability of a similar service for women, the staff claims they "haven't received any requests from them." 54

Additionally, the gendered availability of this service may also demonstrate another difference rooted in basic anatomy. To sexually service a male client, a sex surrogate does not need to perform any act of penetration in order to allow that client to reach orgasm, whereas for a female, the possibility of penetration may be greater, although it is often just as feasible for a woman to reach orgasm without penetration. Even the seemingly progressive White Hands organization may be unconsciously reacting to the differences in services provided for males versus females. The questions they raise on their website ask, first, "what exactly do we do [for women] ... and to what end?" and "would

52. Some scholars argue that sexual release is as much a basic need as the need for sleep or food. See Bahner, supra note 1, at 340, (citing Linda R. Mona, Sexual Options for Persons with Disabilities, 26 WOMEN \& THERAPY 211 (2003)).

53. In contemporary sex therapy, it has been hypothesized that teaching women how to masturbate to orgasm could be an effective way to counter hypoactive sexual desire disorder, which indicates low desire for engaging in sexual activities. See Brian Zamboni \& Isiaah Crawford, Using Masturbation in Sex Therapy: Relationships Between Masturbation, Sexual Desire, and Sexual Fantasy, in Masturbation as a Means of AChiEving SEXUal Health 124, 138-39 (Edmond Coleman \& Walter Bockting eds., 2002).

54. WHITE HANDS, http://www.whitehands.jp/e.html (last visited Apr. 18, 2014). 
this even be considered a care service?"55 This may be a cultural difference, but it demonstrates the gender split between this service for males being looked at solely as a "care service" while the existence of the same needs for women, and whether it constitutes a care service, are debatable. ${ }^{56}$

Homosexuality also presents a uniquely gendered set of stereotypes about males and females. The general public views male and female homosexual behavior differently, and issues of consent may also be based on gender. ${ }^{57}$ Further, it may be possible that a facility would only allow heterosexual encounters based on bias, or homosexual activity between females and not males. These issues of gender-based discrimination of sexual activities must be taken into account when an institution works to determine how to appropriately allow for consensual sexual encounters between patients.

\section{d. How This All Relates to Competency}

The many variations of sexual activity between consenting adults must be considered in the same way that "basic" heterosexual sex is considered. Competence to engage in sexual activity should never be prefaced on the type of activity an individual wishes to engage in, no matter how taboo. An ongoing difficulty in this area is ensuring that all these forms of expression, plus others not covered here, have the same standards of competence applied to them. Elaine Craig writes, "[u]navoidably, a law that denies capacity to consent to a particular sexual act also affects individual liberty. A legal rule that denies capacity to consent to a particular sexual act circumscribes sexual liberty by depriving individuals of the ability to legally engage in sex that they might desire." ${ }^{58}$ Craig highlights a key point: sexual activities that fall outside the "mainstream" deserve equal treatment in facilities, and the

\footnotetext{
55. Id.
}

56. Bahner, supra note 1, at 349. Bahner discusses some of the ambivalences faced by persons with physical disabilities with regard to the role of their caregiver:

When discussing sexual facilitation, none of the participants in this study wished their assistants to assist more than to the most basic degree, e.g. undressing, putting in position, putting on a porn movie, putting on condoms or assisting with other aids. Hence, participants drew the line between receiving assistance in order to be able to be sexual on your own or with partner(s) and receiving assistance in the actual sexual activity, which was thought of as crossing the line.

Id.

57. See generally Lisa Gotell, Governing Heterosexuality Through Specific Consent: Interrogating the Government Effects of R v. J.A., 24 CAN. J. WOMEN \& L. 359 (2012).

58. Elaine Craig, Capacity to Consent to Sexual Risk, 17 NEW CRIM. L. REv. 103, 105 (2014). 
desire to engage in such acts must be recognized by these facilities as being an equally valid sexual desire. Particularly in institutions where individual provider's religious, ethical, or moral beliefs may come into play, ${ }^{59}$ patients must be evaluated equally_regardless of how they choose to express themselves sexually or with what subculture they identify. Unique characteristics and sexual preferences of an individual will not make that individual "less competent" to engage in his or her preferred type of sexual activity, even if it means that such individuals are not consenting in a traditional way but still desire and understand the sexual activity. ${ }^{60}$

Just as a person with a mental disability is entitled to individualized treatment, his or her sexual ability and interests should be viewed as unique characteristics that merit an individual plan and attention. Implementing a universal plan for patients in a facility or in the community outlining a standard measure of acceptable activities and consent will not allow an individual with mental illness to gain pleasure from desired sexual activities. This ability to gain pleasure from sexual activities that appeal to an individual is something that, with few exceptions, society at large is able to do.

\section{JURISPRUDENTIAL INQUIRIES}

\section{A. Introduction}

We now turn to three jurisprudential considerations that, we hope, will give greater depth to this inquiry: the meaning of sanism (and pretextuality), the significance of international human rights law, and the importance of therapeutic jurisprudence to this topic.

59. See Perlin, supra note 9, at 526. ("Even if policies are promulgated that protect and respect the sexual autonomy of institutionalized individuals, what happens when individual line staff at a hospital, the people to whom the implementation of the policy inevitably falls, simply refuse to cooperate with the policy because their own sense of religious 'morality' forbids it?"); see also Bahner, supra note 1, at 338 ("Personal assistants' beliefs and moral judgments have been shown to strongly influence, and cause attitudinal barriers in, sexual expression.").

60. For example, a sadomasochistic sexual encounter may appear to be a "struggle," rather than "traditional" sex in which both parties outwardly appear to enjoy the activity. However, there is still clear consent and safeguards, including a safeword to ensure that either party can stop the activity at any time. The sexual fulfillment is created by the appearance of these power dynamics during the encounter, but in no way distorts the fact that clear consent has been given. See generally Patricia A. Cross \& Kim Matheson, Understanding Sadomasochism: An Empirical Examination of Four Perspectives, 50 J. HOMOSEXUALITY 133 (2006). 


\section{Sanism}

Sanism's corrosive effects have warped mental disability law jurisprudence. ${ }^{61}$ Along with pretextuality, ${ }^{62}$ it has controlled, and continues to control, modern mental disability law. ${ }^{63}$ A careful examination of mental disability law reveals that judges are often pretextual because of their own "instrumental, functional, normative and philosophical" dissatisfaction with non-sanist constitutional decisions that grant a measure of dignity to persons with mental disabilities. ${ }^{64}$ Indeed, deprivation of dignity is often a reflection of sanism on the part of governments and private decision makers. ${ }^{65}$

Sanist myths exert especially great power over lawyers who represent persons with mental disabilities. The use of stereotypes, typification, and de-individualization inevitably means that sanist lawyers will trivialize both their clients' problems and the importance of any eventual solution to these problems. Sanist lawyers implicitly and explicitly question their clients' competence and credibility, a move that significantly impairs the lawyers' advocacy efforts. ${ }^{66}$

61. See Perlin, supra note 14 , at 487.

62. We define pretexuality as the ways in which courts accept (either implicitly or explicitly) testimonial dishonesty and engage similarly in dishonest (and frequently meretricious) decisionmaking. See, e.g., Michael L. Perlin, "Simplify You, Classify You": Stigma, Stereotypes and Civil Rights in Disability Classification Systems, 25 GA. ST. U. L. REV. 607, 621 (2009).

The pretexts of the forensic mental health system are reflected both in the testimony of forensic experts and in the decisions of legislators and fact-finders. Experts frequently testify in accordance with their own self-referential concepts of "morality" and openly subvert statutory and case law criteria that impose rigorous behavioral standards as predicates for commitment or that articulate functional standards as prerequisites for an incompetency to stand trial finding. Often this testimony is further warped by a heuristic bias. Expert witnesses-like the rest of us - succumb to the seductive allure of simplifying cognitive devices in their thinking, and employ such heuristic gambits as the vividness effect or attribution theory in their testimony.

Perlin, supra note 5, at 18 .

63. See Michael L. Perlin, Promoting Social Change in Asia and the Pacific: The Need for a Disability Rights Tribunal to Give Life to the UN Convention on the Rights of Persons with Disabilities, 44 GEO. WASH. INT'L L. REV. 1, 31 (2012).

64. Michael L. Perlin, "Life Is in Mirrors, Death Disappears": Giving Life to Atkins, 33 N.M. L. REV. 315, 344 (2003) (quoting Michael L. Perlin, "There's No Success Like Failureland Failure's No Success at All": Exposing the Pretextuality of Kansas v. Hendricks, 92 Nw. U. L. REv. 1247, $1258(1997))$.

65. See generally Michael L. Perlin, InTernational human Rights and Mental Disability LaW: When the SILENCED ARE HeARd (2011); Michael L. Perlin, The HiddeN Prejudice: Mental Disability on Trial (2000); Michael L. Perlin, Understanding the Intersection Between International Human Rights and Mental Disability Law: The Role of Dignity, in THe Routledge Handbook of InTERnational Crime aNd Justice Studies 191 (Bruce A. Arrigo \& Heather Y. Bersot, eds., 2013).

66. Perlin, supra note 6, at 684; see also Keri K. Gould \& Michael L. Perlin, "Johnny's in the 
The relationship between sanism and dignity must be underscored. ${ }^{67}$ Sanist judicial decisions in cases involving persons with mental disabilities in the full range of sexuality matters rob such individuals of the basic dignity to which they are entitled. ${ }^{68}$

\section{International Human Rights ${ }^{69}$}

The Convention on the Rights of Persons with Disabilities (CRPD) "is regarded as having finally empowered the 'world's largest minority' to claim their rights, and to participate in international and national affairs on an equal basis with others who have achieved specific treaty recognition and protection." ${ }^{70}$ This Convention is the most revolutionary international human rights document ever applied to persons with disabilities. ${ }^{71}$ The CRPD furthers the human rights approach to disability and recognizes the right of people with disabilities to equality in almost every aspect of life. ${ }^{72}$ It firmly endorses a social model of disability-a clear and direct repudiation of the medical model that traditionally was

Basement/Mixing Up His Medicine": Therapeutic Jurisprudence and Clinical Teaching, 24 SEATTLE U. L. REV. 339 (2000).

67. See generally Michael L. Perlin, A Prescription for Dignity: Rethinking Criminal JUSTICE AND MENTAL DISABILITY LAW (2013).

68. On the relationship between dignity and "human worth," see Amanda Ploch, Why Dignity Matters: Dignity and the Right (or Not) to Rehabilitation from International and National Perspectives, 44 N.Y.U. J. INT'L L. \& POL. 887, 895-96 (2012).

69. Portions of this section are adapted from Michael L. Perlin, "Striking for the Guardians and Protectors of the Mind": The Convention on the Rights of Persons with Disabilities and the Future of Guardianship Law, 117 PENN ST. L. REV. 1159, 1173-74 (2013).

70. Rosemary Kayess \& Phillip French, Out of Darkness into Light? Introducing the Convention on the Rights of Persons with Disabilities, 8 HUM. RTS. L. REV. 1, 4 (2008) (footnote omitted). See, e.g., Convention on the Rights of Persons with Disabilities: Special Event, U.N. Human Rights Council (Mar. 26, 2007) (statements of Louise Arbour, High Comm'r for Human Rights \& Ambassador Don Mackay, permanent representative of New Zealand and chair of the ad-hoc committee on a Comprehensive and Integral International Convention on the Protection and Promotion of the Rights and Dignity of Persons with Disabilities), available at http://bit.ly/TzETzv; see also Convention on the Rights of Persons with Disabilities, G.A. Res. 61/106, U.N. Doc. A/RES/61/106 (Jan. 24, 2007) [hereinafter sometimes CRPD]. See generally Kristin Booth Glen, Changing Paradigms: Mental Capacity, Legal Capacity, Guardianship, and Beyond, 44 CoLuM. HuM. RTS. L. REV. 93, 134-37 (2012).

71. See generally Michael L. Perlin \& Eva Szeli, Mental Health Law and Human Rights: Evolution and Contemporary Challenges, in MENTAL HEALTH AND HUMAN RIGHTS: VISION, Praxis, AND Courage 80-94 (Michael Dudley et al. eds., 2012); PERlin, When the Silenced ARE HEARD, supra note 65, at 3-21.

72. See, e.g., Aaron A. Dhir, Human Rights Treaty Drafting Through the Lens of Mental Disability: The Proposed International Convention on Protection and Promotion of the Rights and Dignity of Persons with Disabilities, 41 STAN. J. INT'L L. 181, 199 (2005). 
part-and-parcel of mental disability law. "The Convention responds to traditional models, situates disability within a social model framework, and sketches the full range of human rights that apply to all human beings, all with a particular application to the lives of persons with disabilities." ${ }^{74}$ It provides a framework for ensuring that mental health laws "fully recognise the rights of those with mental illness." 75 There is no question that it has "ushered in a new era of disability rights policy." 76

This Convention demands we reconsider the issues discussed in this Article. ${ }^{77}$ In light of Convention Articles mandating, inter alia, "respect for inherent dignity,"78 the elimination of discrimination in all matters related to interpersonal relationships, ${ }^{79}$ and services in the area of sexual and reproductive health, ${ }^{80}$ it is time for a radical change of perspective and attitude in how society views the sexuality, and right to express that sexuality, of persons with disabilities. Society as a whole must, as international law already has, recognize that " $[\mathrm{b}]$ eing deemed a 'person' or sexual is not contingent upon ability." 81 Yet, the literature surrounding the sexual autonomy and issues of sexuality people with disabilities continue to confront remains remarkably silent on this issue

73. See generally Michael L. Perlin, "Abandoned Love": The Impact of Wyatt v. Stickney on the Intersection Between International Human Rights and Domestic Mental Disability Law, 35 LAW \& PSYCHOL. REV. 121 (2011).

74. Janet E. Lord \& Michael A. Stein, Social Rights and the Relational Value of the Rights to Participate in Spont, Recreation, and Play, 27 B.U. INT'L L.J. 249, 256 (2009). For additional research on how the CRPD fits within a social framework, see Janet E. Lord, David Suozzi \& Allyn L. Taylor, Lessons from the Experience of U.N. Convention on the Rights of Persons with Disabilities: Addressing the Democratic Deficit in Global Health Governance, 38 J.L. MED. \& EтнICS 564, 568 (2010); H. Archibald Kaiser, Canadian Mental Health Law: The Slow Process of Redirecting the Ship of State, 17 HEALTH L.J. 139, 164 (2009); Ronald McCallum, The United Nations Convention on the Rights of Persons with Disabilities: Some Reflections (Sydney Law Sch. Research Paper No. 10/30, 2010), available at http://papers.ssrn.com/sol3/papers.cfm? abstract_id=1563883.

75. Bernadette McSherry, International Trends in Mental Health Laws: Introduction, 26 LAW IN CONTEXT 1, 8 (2008).

76. Paul Harpur, Time to Be Heard: How Advocates Can Use the Convention on the Rights of Persons with Disabilities to Drive Change, 45 VAL. U. L. REV. 1271, 1295 (2011).

77. See generally Perlin \& Lynch, supra note 2.

78. CRPD, supra note 70, at art. 3(a). On how dignity is the first "fundamental axiom" upon which the CRPD is premised, see Raymond Lang, The United Nations Convention on the Right and Dignities for Persons with Disabilities: A Panacea for Ending Disability Discrimination?, 3 EUR. J. DISABILITY 266, 273 (2009).

79. See CRPD, supra note 70, at art. 23.

80. Id. at art. 25 .

81. Bethany Stevens, Structural Barriers to Sexual Autonomy for Disabled People, 38 HUM. RTS. 14 (2011); Girlescu, supra note 24, at 16. 
in general, ${ }^{82}$ and totally silent about the rights to sexual autonomy for persons institutionalized because of psychosocial or intellectual disability. ${ }^{83}$

Professors Michael Stein and Janet Lord have written eloquently about how another Article in the convention-Article 30, setting out social rights of participation in cultural life - "serves as a vital channel of engagement with society when such participation is embraced by the community," and increases "self-reliance and empowerment." 84 If the Convention is taken seriously - if it is, in fact, more than a "paper victor[y] " sanism that continues to deny the sexuality rights of institutionalized persons with mental disabilities. ${ }^{86}$

82. On how the entire question is often seen as "taboo," see, for example, Michael L. Perlin, "Make Promises by the Hour": Sex, Drugs, the ADA, and Psychiatric Hospitalization, 46 DEPAUL L. REv. 947, 965 (1997) ("The taboo and stigma attached to sexual behavior is inevitably heightened when it is coupled with and conflated with stereotypes of the meaning of mental disability."). For a clinical perspective, see, for example, McCann, supra note 13. On how the controversy over masturbation reflects social taboos, see Gill, supra note 26, at 482.

83. Special issues may be raised in cases of individuals with autism or those with autism spectrum disorders (ASD). Compare Gilmour, Smith \& Schalomon, supra note 1 (stating that most people with ASD have sexual interests and engage in sexual behaviors with others), with Laura Gilmour, Melike Schalomon \& Veronica Smith, Sexuality in a Community Based Sample of Adults with Autism Spectrum Disorder, 5 RES. IN AUTISM SPECTRUM DisORDERS 313 (2012) (arguing that although individuals with ASD display an interest in sex and engage in sexual behaviors and showed no significant differences in breadth and strength of sexual behaviors and comprehension of sexual language when contrasted with non-ASD participants, nonetheless, a higher rate of asexuality was found among individuals with ASD). For a recent consideration of asexuality as a category of legal analysis, see generally Elizabeth Emens, Compulsory Sexuality, 66 STAN. L. REV. 303 (2014). See also Gill, supra note 26, at 487 (discussing individuals who may wish to choose an asexual lifestyle).

84. Michael Ashley Stein \& Janet Lord, Jacobus tenBroek, Participatory Justice, and the UN Convention on the Rights of Persons with Disabilities, 13 TEX. J. C.L. \& C.R. 167, 182 (2008) (discussed extensively in Michael L. Perlin, "Through the Wild Cathedral Evening": Barriers, Attitudes, Participatory Democracy, Professor tenBroek, and the Rights of Persons with Mental Disabilities, 13 TEX. J. on C.L. \& C.R. 413 (2008)).

85. Michael L. Perlin, "What's Good is Bad, What's Bad is Good, You'll Find Out When You Reach the Top You're on the Bottom": Are the Americans with Disabilities Act (and Olmstead v. L.C.) Anything More Than "Idiot Wind?", 35 U. Mich. J.L. REFORM 235, 246 (2002) ("Mental disability law is strewn with examples of "paper victories." (quoting Michael Lottman, Paper Victories and Hard Realities, in PAPER VICTORIES AND HARD REALITIES: THE IMPLEMENTATION OF THE LEGAL AND CONSTITUTIONAL RightS OF THE MENTALLY DiSABLED 93 (Valerie J. Bradley \& Gary J. Clarke eds., 1976))). In the specific context of United Nations Conventions, see Sara Dillon, What Human Rights Law Obscures: Global Sex Trafficking and the Demand for Children, 17 UCLA WOMEN's L.J. 121, 154 (2008) ("A specialized human rights convention does not in itself guarantee substantial change.").

86. There is some evidence that in other jurisdictions, parallel rights are being taken seriously. See, e.g., Convention for the Protection of Human Rights and Fundamental Freedoms, art. 8(1) (amended by Protocol No. 11, Nov. 1, 1998), available at http://conventions.coe.int/treaty/ 
In an earlier paper, we considered the few scholarly articles in the literature that stand out as rare examples of what scholars should be thinking about: ${ }^{87}$ Maya Sabatello's paper on the intersection between infertility, reproductive technologies, and disability rights law; ${ }^{88}$ her paper on how sexuality was considered in the debate on the CRPD; ${ }^{89}$ and, most directly, Marta Schaaf's article on sexuality in the context of the CRPD. ${ }^{90}$ Drawing on Articles 2 (one of the "reasonable accommodation" articles), 23 and 26, Sabatello concludes that the CRPD provides a "possible venue to further advance a right to found a family through [assisted reproductive technologies]."91 In assessing the drafting process, Sabatello notes how all conversations about sexuality "raised acute debates," 92 and that, as a result, sexuality per se "was not elevated to the status of a right." ${ }^{.93}$ Schaaf - who frontally notes that disabled sexuality is often perceived as a "threat to others" " - discussed the "tension" that underlaid the negotiations leading to the adoption of the CRPD "between efforts to promote sexual rights and efforts to protect [persons with disabilities] from unwanted sterilization." ${ }^{95}$ Schaaf

en/treaties/html/005.htm (as construed in X. v. Iceland, App. No. 6825/74, 5 Eur. Comm'n H.R. Dec. \& Rep. 86 (1976)) (article prohibiting public authorities from interfering with a person's right "to respect for his private and family life, his home and his correspondence" is broad enough to encompass an entitlement "to establish and to develop relationships with other human beings, especially in the emotional field for the development and fulfillment of one's own personality"); Lawrence O. Gostin \& Lance Gable, The Human Rights of People with Mental Disabilities: A Global Perspective on the Application of Human Rights Principles to Mental Health, 63 MD. L. REV. 20, 94 (2004).

87. See Perlin \& Lynch, supra note 2 .

88. Maya Sabatello, Who's Got Parental Rights? The Intersection Between Infertility, Reproductive Technologies, and Disability Rights Law, 6 J. HEALTH \& BIOMEDICAL L. 227 (2010). See generally Stevens, supra note 81, at 16. Another crucial issue in the lives of disabled people is the experience of legal intervention to deny parental rights. Denial of parental rights occurs across types of disabilities but occurs perhaps most fervently with intellectually and developmentally disabled people - as in many cases they lack the autonomy to consent to sexual activity, the choice to reproduce, and the ability to retain children after birth. See, e.g., Bethany Stevens, Structural Barriers to Sexual Autonomy for Disabled People, 38 HuM. RTs. 14 (2011); Duffy Dillon, Child Custody and the Developmentally Disabled Parent, 2000 WIS. L. REV. 127.

89. Maya Sabatello, Disability, Human Rights and Global Health: Past, Present, Future, in 16 Law and Global Health Current Legal Issues 244 (M. Freeman et al. eds., 2014) (in press).

90. Marta Schaaf, Negotiating Sexuality in the Convention on the Rights of Persons with Disabilities, 8 Sur InT'L J. Hum. RTS. 113 (2011).

91. Sabatello, supra note 88, at 259.

92. Sabatello, supra note 89, at 257.

93. Id. On the opposition of the Arab Group of nations, the Holy See and Yemen to expanded mention of sexuality - unmoored from traditional marriage - see $i d$.

94. Schaaf, supra note 90 , at 114.

95. Id. at 124. 
notes that disability-focused NGOs "continue to be reluctant to engage sexuality," claiming will likely continue to grow, providing greater and better opportunities to move beyond current understandings of sexual citizenship to include disabled and all other bodies." $" 97$

Throughout the CRPD, it is apparent that the preferences and decisions of persons with disabilities must be respected and promoted. ${ }^{98}$ Expanding on this idea of self-determination, it follows that decisions about sex, sexuality and reproduction are to be made by the person with a disability, rather than a "caretaker" or a facility superintendent. ${ }^{99}$ This kind of decision-making is a core element of self-determination and empowerment.

\section{Therapeutic Jurisprudence ${ }^{100}$}

Another important lens through which to view this issue is that of therapeutic jurisprudence. Therapeutic jurisprudence (TJ) "asks us to look at law as it actually impacts people's lives" 101 and focuses on the law's influence on emotional life and psychological well-being. ${ }^{102}$ It suggests that "law should value psychological health, should strive to avoid imposing anti-therapeutic consequences whenever possible, andwhen consistent with other values served by law-should attempt to bring about healing and wellness." 103 The ultimate aim of TJ is to determine whether legal rules and procedures or lawyer roles can or should be reshaped to enhance their therapeutic potential while not subordinating due process principles. ${ }^{104}$ There is an inherent tension in

96. $I d$

97. Id. at 125 .

98. Cf. Bahner, supra note 1, at 338 (discussing Sweden) ("Even though the article 23 covers the right to a sexual life, this aspect has not been implemented in personal assistance services.").

99. See Judith A. Cook, Sexuality and People with Psychiatric Disabilities, 18 SEXUALITY AND DISABILITY 195, 203 (2000).

100. Portions of this section are adapted from Perlin \& Lynch, supra note 2.

101. Bruce J. Winick, Foreword: Therapeutic Jurisprudence Perspectives on Dealing with Victims of Crime, 33 Nova L. REV. 535, 535 (2009).

102. See David B. Wexler, Practicing Therapeutic Jurisprudence: Psycholegal Soft Spots and Strategies, in Dennis P. Stolle et AL., Practicing Therapeutic Jurisprudence: LAW AS A HeLring Profession 45 (2000).

103. Bruce J. Winick, A Therapeutic Jurisprudence Model for Civil Commitment, in INVOLUNTARY DETENTION AND THERAPEUTIC JURISPRUDENCE: INTERNATIONAL PERSPECTIVE ON Civil Commitment 23, 26 (Kate Diesfeld \& Ian Freckelton eds., 2003).

104. See Michael L. Perlin, "And My Best Friend, My Doctor/Won't Even Say What It Is I've Got": The Role and Significance of Counsel in Right to Refuse Treatment Cases, 42 SAN DIEGO L. 
this inquiry. David Wexler clearly identifies how it must be resolved: The law's use of "mental health information to improve therapeutic functioning [cannot] impinge[] upon justice concerns." 105 As one of the authors has written elsewhere, "an inquiry into therapeutic outcomes does not mean that therapeutic concerns 'trump' civil rights and civil liberties." 106 In its aim to use the law to empower individuals, enhance rights, and promote well-being, $\mathrm{TJ}$ has been described as "a sea-change in ethical thinking about the role of law ... a movement towards a more distinctly relational approach to the practice of law... which emphasises psychological wellness over adversarial triumphalism."107 That is, TJ supports an ethic of care. ${ }^{108}$

One of the central principles of $\mathrm{TJ}$ is a commitment to dignity. ${ }^{109}$ Professor Amy Ronner describes the "three Vs" as voice, validation, and voluntariness, ${ }^{110}$ arguing:

What "the three Vs" commend is pretty basic: litigants must

REv. 735, 751 (2005); see also Michael L. Perlin, "Baby, Look Inside Your Mirror": The Legal Profession's Willful and Sanist Blindness to Lawyers with Mental Disabilities, 69 U. PITT. L. REV. 589, 591 (2008) (discussing how TJ "might be a redemptive tool in efforts to combat sanism, as a means of 'strip[ping] bare the law's sanist façade'"); Bernard P. Perlmutter, George's Story: Voice and Transformation Through the Teaching and Practice of Therapeutic Jurisprudence in a Law School Child Advocacy Clinic, 17 ST. Thomas L. REV. 561, 599 n.111 (2005); Ian Freckelton, Therapeutic Jurisprudence Misunderstood and Misrepresented: The Price and Risks of Influence, 30 T. JEFFERSON L. REV. 575, 585-86 (2008).

105. See David B. Wexler, Therapeutic Jurisprudence and Changing Concepts of Legal Scholarship, 11 BEHAV. SCI. \& L. 17, 21 (1993); David Wexler, Applying the Law Therapeutically, 5 APPLIED \& PREVENTIVE PSYCHOL. 179, 184 (1996).

106. Michael L. Perlin, A Law of Healing, 68 U. CN. L. REv. 407, 412 (2000); Michael L. Perlin, "Where the Winds Hit Heavy on the Borderline": Mental Disability Law, Theory and Practice, "Us" and "Them," 31 LOY. L.A. L. REV. 775, 782 (1998).

107. Warren Brookbanks, Therapeutic Jurisprudence: Conceiving an Ethical Framework, 8 J.L. \& MED. 328, 329-30 (2001); see also Bruce J. Winick, Overcoming Psychological Barriers to Settlement: Challenges for the TJ Lawyer, in THE AFFECTIVE Assistance OF COUNSEL: Practicing LaW as a Healing Profession 342 (Marjorie A. Silver ed., 2007); Bruce J. Winick \& David B. Wexler, The Use of Therapeutic Jurisprudence in Law School Clinical Education: Transforming the Criminal Law Clinic, 13 CLINICAL L. REv. 605, 605-06 (2006). The use of the phrase dates to CAROL GILLIGAN, IN A DIFFERENT VOICE (1982).

108. See, e.g., Winick \& Wexler, supra note 107, at 605-07; David B. Wexler, Not Such a Party Pooper: An Attempt to Accommodate (Many of) Professor Quinn's Concems About Therapeutic Jurisprudence Criminal Defense Lawyering, 48 B.C. L. REV. 597, 599 (2007); Brookbanks, supra note 107; Gregory Baker, Do You Hear the Knocking at the Door? A "Therapeutic" Approach to Enriching Clinical Legal Education Comes Calling, 28 WHITTER L. REV. 379, 385 (2006).

109. See Bruce J. Winick, Civil Commitment: A Therapeutic Jurisprudence Model 161 (2005).

110. Amy D. Ronner, The Learned-Helpless Lawyer: Clinical Legal Education and Therapeutic Jurisprudence as Antidotes to Bartleby Syndrome, 24 TOURO L. REV. 601, 627 (2008). On the importance of "voice," see Freckelton, supra note 104, at 588. 
have a sense of voice or a chance to tell their story to a decision maker. If that litigant feels that the tribunal has genuinely listened to, heard, and taken seriously the litigant's story, the litigant feels a sense of validation. When litigants emerge from a legal proceeding with a sense of voice and validation, they are more at peace with the outcome. Voice and validation create a sense of voluntary participation, one in which the litigant experiences the proceeding as less coercive. Specifically, the feeling on the part of litigants that they voluntarily partook in the very process that engendered the end result or the very judicial pronunciation that affects their own lives can initiate healing and bring about improved behavior in the future. In general, human beings prosper when they feel that they are making, or at least participating in, their own decisions. ${ }^{111}$

The questions that must be addressed here are these: Are persons with mental disabilities given this sort of autonomy in their sexual decision making? Are Professor Ronner's "three V's" complied with?

While the sexual components of competency are a critical consideration, especially for those individuals confined in a psychiatric facility, there are a multitude of other issues that involve a presumption of competency (or, alternatively, the presumption of incompetency). ${ }^{112}$ When the presumption of incompetency exists, so too does the possibility for disparate treatment of people-virtually always improperly_deemed incompetent. In the following sections, we provide examples of contexts in which competency is discussed in statutes or case law, and we attempt to make clear where individuals deemed incompetent may face discrimination due to their mental disabilities.

\section{MARRIAGE ${ }^{113}$}

Marriage has long been considered a fundamental right guaranteed by the Fourteenth Amendment to the U.S. Constitution, however, recent U.S. Supreme Court, lower federal court, and state court decisions have embraced and endorsed the right for broader equality in the right to marry. ${ }^{114}$ These decisions have raised the question of whether "the right

111. Amy D. Ronner, Songs of Validation, Voice, and Voluntary Participation: Therapeutic Jurisprudence, Miranda and Juveniles, 71 U. CIN. L. REV. 89, 94-95 (2002) (citations omitted).

112. Cf. supra note 29 (presumption of incompetency disallowed in the law).

113. This section is adapted from PERLIN ET AL., supra note 20, at 269-75.

114. See, e.g., United States v. Windsor, _U.S._, 133 S. Ct. 2675 (2013) (federal statute defining marriage as solely being between man and woman was unconstitutional as a deprivation of the liberty of the person protected by the Fifth Amendment). See also, Cass R. Sunstein, The Right 
to marry" falls under an equal protection or due process argument. ${ }^{115}$ Marriage itself is viewed as such an important right in the United States that, historically, there has been very little interference allowed by the states, although the state may impose reasonable requirements if they pose no significant interference with the marital relationship. ${ }^{116}$ Substantial interference with the decision to marry is permissible only if important state interests are at stake and the regulation is closely tailored to effectuate the state's interests. ${ }^{117}$ Marriage statutes have typically been created using "capacity" as a determinative factor, rather than "competency." Using an analysis of competency leads to a novel discussion that, so far, has not taken place in many laws or statutes.

Historically, consistent with constitutional guarantees, the statutory requirements for marriage between a man and woman were generally minimal. ${ }^{118}$ For others not conforming to these statutorily-implemented standards, statutory requirements had barred them from marrying. ${ }^{119}$ Every marriage requires capacity on the part of both individuals to enter into the relationship. ${ }^{120}$ This stems from the conception of marriage as a contract, as well as a social status. ${ }^{121}$ There is no question that, as plaintiffs continue to be successful in same-sex marriage cases, the issues that we are discussing in this Article will inevitably emerge in such cases as well.

\footnotetext{
to Marry, 26 CARDOZO L. REV. 2081, 2089 (2005):

Very oddly, the Tumer Court did not specify whether the right to marry is rooted in substantive due process (as Loving suggested) or in the fundamental rights branch of equal protection doctrine (the most sensible reading of Zablocki). It would be fair to read the Court as treating marriage as akin to other privacy rights, in a way that suggests that substantive due process is involved. But for purposes of reaching its conclusion, the Court did not have to choose between the two possible sources of its decision.

115. See, e.g., Loving v. Virginia, 388 U.S. 1, 12 (1967) (invalidating a state miscegenation statute on both equal protection and due process grounds).

116. See, e.g., Tumer v. Safley, 482 U.S. 78, 93 (1978) (invalidating an inmate marriage regulation which prohibited inmates from marrying other inmates or civilians unless prison superintendent determined that there were compelling reasons because the regulation was not reasonably related to any penological objective).

117. Id.

118. See, e.g., Mich. Comp. Laws ANN. $\$ 551.103$ (LexisNexis 2007); TeX. Fam. CodE ANN. $\S 2.001$ (West 2006).

119. On inability to consent to marriage due to mental incapacity, see, for example, CAL. FAM. CODE $\$ 2210$ (c) (West 2013).
}

120. See, e.g., Mahan v. Mahan, 88 So. 2d 545, 547 (Fla. 1956).

121. Edmunds v. Edwards, 287 N.W.2d 420, 425 (Neb. 1980). 


\section{A. Mental Capacity to Marry}

As in other areas of civil law, individuals are presumed to possess capacity in the absence of a determination to the contrary. ${ }^{122}$ Moreover, a presumption of validity applies to marriages, reflecting the state's interest in promoting and protecting marriage and family. ${ }^{123}$

The best accepted standard for mental capacity to marry is whether the individual understands the nature of the marriage contract and the duties and responsibilities it creates. ${ }^{124}$ The language of this standard parallels the capacity standard for ordinary contracts, but the meaning is quite different due to the vast differences in the responsibilities and consequences of marriage as opposed to those stemming from engaging in ordinary business transactions. ${ }^{125}$ As one court described it:

[Marriage,] in many cases, depends more on sentiments of mutual esteem, attachment, and affection, which the weakest may feel as well as the strongest intellects, than on the exercise of a clear, unclouded reason, or sound judgment, or intelligent discernment and discrimination, and in which it differs in a very important respect from all other contracts. ${ }^{126}$

Few cases specify what an individual must understand about the "nature of marriage" or the attendant "duties and responsibilities" in order to satisfy the marriage capacity standard. A contractual perspective would suggest that the material provisions of the marriage contract would define the understanding required for capacity to marry. Cases eschew such a formalistic approach, instead emphasizing the factspecific nature of the capacity determination.

122. Accounts Mgmt. Inc. v. Litchfield, 576 N.W.2d 233, 234 (S.D. 1998) (marriage statute should be construed to favor validation even when full compliance with formalities may be defective); De la Montanya v. De la Montanya, 281 P. 825, 825 (Or. 1929) (presumptive validity of marriage). But see Gamez v. Indus. Comm'n, 559 P.2d 1094, 1100 (Ariz. Ct. App. 1976) (marriage that fails to comply with statutory requirements is invalid).

123. Greathouse v. Vosburgh, 169 N.E.2d 97, 103 (Ill. 1960); Eygabrood v. Gruis, 79 N.W.2d 215, 217 (Iowa 1956); Brown v. State, 66 S.E.2d 745, 748 (Ga. 1951).

124. See, e.g., In re Estate of Hendrickson, 805 P.2d 20, 23 (Kan. 1991); Johnson v. Johnson, 104 N.W.2d 8, 14 (N.D. 1960); Cook v. Cook, 243 S.W.2d 900, 901 (Ky. 1951).

125. See, e.g., MinN. STAT. ANN. $\$ 517.01$ (West 2006) (establishing contractual capacity as applicable to marriage).

126. Johnson, 104 N.W.2d at 14. See also Edmunds v. Edwards, 287 N.W.2d 420, 425 (Neb. 1980) ("[Marriage] is not a contract resembling in any but the slightest degree, except as to the element of consent, any other contract with which the courts have to deal, is apparent upon a moment's reflection. *** What persons establish by entering into matrimony, is not a contractual relation, but a social status; and the only essential features of the transactions are that the participants are of legal capacity to assume that status, and freely consent so to do." (internal quotation marks omitted)). 
The formalistic approach was explicitly rejected in the case of Ivery $v$. Ivery, ${ }^{127}$ involving a daughter's challenge to the marriage of her deceased father. ${ }^{128}$ The jury found that the father lacked capacity to marry, and the father's wife appealed. ${ }^{129}$ The Supreme Court of North Carolina reversed and ordered a new trial on the grounds that the jury instructions given by the trial court incorrectly suggested that marriage capacity required the ability to understand the applicable intestacy statute as well as the revocatory effect of marriage on wills pre-dating the marriage. ${ }^{130}$ In other words, capacity to marry does not necessarily require an appreciation of the panoply of property rights of a surviving spouse.

As in the case of other capacity doctrines in the civil law, capacity to marry need exist only at the time of marriage. ${ }^{131}$ Proof of a mental disability that ordinarily compromises the capacity to marry will not invalidate a marriage entered into during a "lucid interval." "132 This is another means by which courts can enforce the policy of preserving marriage. $^{133}$

\section{B. Context and Standing}

Claims of incapacity to marry arise in three basic contexts: (1) one spouse seeks annulment after a period of living with the other spouse as a married couple (2) a guardian or family member seeks annulment during the lifetime of the spouses; and (3) a guardian or family member seeks annulment after the death of one of the spouses. Not all of these claims are viable in all jurisdictions. Restrictions on who has standing to sue, the time in which the annulment suit must be brought, and the form

\footnotetext{
127. 129 S.E.2d 457 (N.C. 1963).

128. $I d$.

129. Id. at 458

130. Id. at $464-65$.

131. Briggs v. Briggs, 325 P.2d 219, 224 (Cal. Dist. Ct. App. 1958); Mahan v. Mahan, 88 So. 2d 545, 547 (Fla. 1956); DeMedio v. DeMedio, 257 A.2d 290, 298 (Pa. Super. Ct. 1969). Several years after the DeMedio decision, the Supreme Court of Pennsylvania rejected DeMedio's conclusion that Pennsylvania's divorce statute prohibits a party from raising equitable defenses to an annulment. Diamond v. Diamond, 461 A.2d 1227, 1229 (Pa. 1983). The effect (though not necessarily the purpose) of recognizing the availability of equitable defenses to annulment is to support the policy of preserving marriage.

132. Briggs, 325 P.2d at 224.

133. Lott v. Toomey, 477 So. $2 d$ 316, 320 (Ala. 1985) (once established, common law marriage is presumed valid and party attacking marriage has burden of proof); In re Estate of Wagner, 893 P.2d 211, 214 (Idaho 1995) (same); Guzman v. Alvarez, 205 S.W.3d 375, 380 (Tenn. 2006) (ceremonial marriage presumed valid).
} 
of the suit vary by jurisdiction depending on statutes governing marriage, guardianship, and civil procedure as well as common law principles of standing, collateral attack of judgments, and other doctrines.

\section{Spouse Seeks Annulment}

In general, one spouse may seek annulment of a marriage to the other spouse based on incapacity. In a few jurisdictions, however, only the spouse alleged to lack capacity may assert the claim; a competent spouse who wants to dissolve the marriage must pursue divorce. ${ }^{134}$

Historically, annulment did not justify judicial re-arrangement of the parties' property rights because alimony, property division, and community property all flowed from marriage. ${ }^{135}$ Annulment of the marriage would void it from inception, leaving no basis upon which to order spousal support, alimony, or division of property. ${ }^{136}$ Early cases reflect the advantage that annulment offered to a propertied spouse, as compared to divorce, where alimony and property division were routine. ${ }^{137}$

In Forbis v. Forbis, ${ }^{138}$ for example, Mrs. Forbis petitioned the court for separate maintenance after Mr. Forbis refused to permit her to return to their marital home following a stay in an insane asylum (this, by the way, was a 1955 case). ${ }^{139}$ Mr. Forbis responded to the claim by seeking

134. ALASKA. STAT. ANN. $\$ \$ 25.05 .031,13.26 .150(\mathrm{e})(8)$ (2006) (cannot prohibit marriage or divorce of a ward; only mentally impaired spouse may seek annulment on grounds of incapacity); N.Y. DOM. REL. LAW \$140 (McKinney 1999) (competent spouse cannot seek annulment of marriage to a mentally retarded spouse; competent spouse cannot seek annulment of marriage to mentally ill spouse after mentally ill spouse's death); OKLA. STAT. ANN. tit. 43, $\$ 128$ (West 2001); WASH REV. CODE ANN. $\$ 26.04 .130$ (West 2005) (marriage voidable only at the election of the party under disability). Florida specifically denies the guardian the power to determine whether a ward marries, instead requiring court approval. FLA. STAT. ANN. $\$ 744.3215(2)$ (a) (West Supp. 2007).

135. Some jurisdictions adhere to the common law rule. See, e.g., Williams v. Williams, 97 P.3d 1124, 1127 (Nev. 2004), reh'g denied, 2004 Nev. Lexis 115 (Nev. Nov. 9, 2004); Shoustari v. Zamani, 574 S.E.2d 314, 315 (Va. Ct. App. 2002). Several jurisdictions, however, have deviated from the common law rule in order to provide relief for the spouse requiring permanent maintenance (alimony) or property division. See, e.g., White v. White, 323 S.E.2d 521, 522 (S.C. 1984); Callaway v. Callaway, 739 So. 2d 1134, 1137 (Ala. Civ. App. 1999); Falk v. Falk, 462 N.W.2d 547, 549 (Wis. Ct. App. 1990); Ranieri v. Ranieri, 539 N.Y.S.2d 382 (N.Y. App. Div. 1989), appeal dismissed, Ranieri v. Ranieri, 545 N.Y.S.2d 106 (N.Y. 1989).

136. See supra note 135 .

137. See, e.g., infra text accompanying notes $138-41$.

138. 274 S.W.2d 800 (Mo. Ct. App. 1955).

139. Id. at 803 . 
annulment on the grounds of Mrs. Forbis' incapacity to marry. ${ }^{140}$ After observing that the presumption of validity of a marriage is "one of the strongest known to the law," the court affirmed the lower court's judgment awarding separate maintenance to Mrs. Forbis and denying Mr. Forbis' claim for annulment. ${ }^{141}$

Before the advent of no-fault divorce, annulment offered potential relief for a spouse who had no grounds for divorce but did have grounds to assert incapacity. In some cases, nearly a decade or more elapsed between the marriage and the application for annulment. ${ }^{142}$ In these cases, the spouse alleged to lack capacity to marry typically suffered from a chronic mental illness or other disability that predated the marriage. ${ }^{143}$ Courts usually refused to annul such marriages, invoking the lucid interval doctrine to refute the contention that chronic mental illness could itself establish incapacity to marry. ${ }^{144}$

Today, the availability of no-fault divorce eliminates the motivation to use one spouse's mental illness as a means of annulling the marriage where no grounds for divorce exist. The property motive for preferring annulment to divorce also has largely disappeared because many jurisdictions, recognizing the potential for unfairness, expanded courts' authority to order alimony or property division upon annulment. This development has decreased the incentive for a spouse to seek annulment rather than divorce. ${ }^{145}$

\section{Guardian or Family Member Seeks Annulment During Spouses' Lifetime}

In order for a guardian to maintain an action for annulment on behalf of the ward, the guardian must have that particular authority, either by statute or by court order. Several jurisdictions have enacted statutes that specifically authorize guardians to petition for annulment on behalf of

140. $I d$.

141. $I d$. at 806,809 .

142. DeMedio v. DeMedio, 257 A.2d 290, 292 (Pa. Super. Ct. 1969); Cook v. Cook, 243 S.W.2d 900, 901 (Ky. 1951).

143. See infra text accompanying note 144 .

144. DeMedio, 247 A.2d at 292; see also Larson v. Larson, 192 N.E.2d 594, 598 (Ill. App. Ct. 1963); Forbis, 274 S.W.2d at 805.

145. See, e.g., N.Y. DoM. REL. LAW $\$ 140$, Commentaries C 140:1 (McKinney 1999) ("reasonable explanation" for the drop in annulments is that it is easier to plead and obtain divorce). See generally David B. Perlmutter, Annotation, Incapacity for Sexual Intercourse as Ground for Annulment, 52 A.L.R.3d 589 (1973); Kerry Abrams, The End of Annulment, 16 J. GEND. RACE \& JUST. 681 (2013). 
their wards. ${ }^{146}$ In most other jurisdictions, courts have concluded that the guardian's general authority includes the power to seek annulment on behalf of the ward. ${ }^{147}$

In a few cases, courts have based their decisions about a guardian's authority over a ward's marriage on their guardianship statutes' provision governing the effect of guardianship on contracts. ${ }^{148}$ Under this analysis, a marriage, like any other contract executed after authority over the subject matter of the contract has been transferred from ward to guardian, is void. Without a specific reference to marriage in the guardianship statute, "contracts" could be interpreted more narrowly, applying only to ordinary business contracts. The difference between the capacity required for ordinary contracts and the capacity required for marriage would seem to justify the more restrictive interpretation of the statutory consequences of guardianship. Another factor weighing in favor of the narrower statutory interpretation, consistent with the ward's protection, is the policy favoring the least restrictive limitations on a ward's autonomy. ${ }^{149}$

Courts have not missed these points; instead they have focused on protection of the ward. This approach is understandable in the context of Knight v. Radmoski, ${ }^{150}$ a case that involved the marriage of an institutionalized, severely brain-damaged young man to his treating psychologist. ${ }^{151}$ The psychologist sought, but did not receive, the approval of her fiancé's father for the marriage. ${ }^{152}$ The father, who had previously been appointed conservator of his son's estate, had further sought appointment as guardian. ${ }^{153}$ On the same day the guardianship was approved, the son married the psychologist, and the two left the

146. See, e.g., OKLA. STAT. ANN. tit. 43, \$ 112 (West 2014); S.D. CoDIFIED LAWs $§ 25-3-2$ (1999); TEX. FAM. CODE. ANN. § 6.108(a) (West 2006); Wyo. STAT. ANn. §20-2-101(d) (West 2013).

147. See, e.g., In re Marriage of Drews, 503 N.E.2d 339 (Ill. 1986), cert denied and appeal dismissed, 483 U.S. 1001 (1987); Nave v. Nave, 173 S.W.3d 766, 771 (Tenn. Ct. App. 2005), appeal denied, 2005 Tenn. LEXIS 904 (Tenn. Oct. 17, 2005); Krukowsky v. Krukowsky, 49 Pa. D \& C.2d 651, 653 (1970). See generally David E. Rigney, Annotation, Power of Incompetent Spouse's Guardian or Representative to Sue for Granting or Vacation of Divorce or Annulment of Marriage, or to Make Compromise or Settlement in Such Suit, 32 A.L.R. 5th 673 (1995).

148. Knight v. Radomski, 414 A.2d 1211, 1215-16 (Me. 1980); In re Matter of Johnson, 658 N.Y.S.2d 780, 78485 (N.Y. Sup. Ct. 1997).

149. See PERtin ET AL., supra note 20, ch. 5 D.2.

150. 414 A.2d 1211 (Me. 1980).

151. Id. at $1212-13$.

152. Id. at 1216.

153. Id. at 1212 . 
Maine institution to live in Colorado. ${ }^{154}$ Noting the severe harm that the marriage and the move had caused the ward, the court held that a guardian's approval was a necessary prerequisite to marriage and that marriage without consent is voidable. On this theory the guardian had standing to seek annulment, which the court granted. ${ }^{155}$

\section{Guardian or Family Member Seeks Annulment After Death of a Spouse}

After the death of either party to the marriage, annulment may be unavailable. Traditional legal theory distinguishes between "void" and merely "voidable" marriages. The theory allows suits after the death of a spouse if the marriage was void, but not if it was merely voidable. ${ }^{156} \mathrm{At}$ common law, mental incapacity resulted in a void marriage, as did bigamy, incest and other fundamental violations of public policy. ${ }^{157}$ Less serious defects in a marriage, such as fraud, resulted in the marriage being merely voidable. ${ }^{158}$

Today, several jurisdictions classify a marriage involving a spouse who lacked capacity to marry as voidable rather than void. Following the common law distinction between void and voidable transactions, classification of a transaction as voidable causes the action to abate after the death of either of the spouses. ${ }^{159}$ Some states specify by statute when and whether an annulment action abates. ${ }^{160}$ Where statutes do not

\footnotetext{
154. Id. at $1212-13$.

155. Id. at 1216.
}

156. In re Santolino, 895 A.2d 506, 509-10 (N.J. Super. Ct. Ch. Div. 2005) (discussing history of void versus voidable distinction as applied to marriage annulment after the death of a spouse, and concluding that the prevailing rule continues to provide that a void marriage may be annulled after the death of one of the parties absent a statutory to the contrary).

157. See generally Annotation, Marriage of Mental Incompetent as Void or Voidable, L.R.A. 1916C, at 700 (1919), cited in Terry L. Turnipseed, How Do I Love Thee, Let Me Count the Days: Deathbed Marriages in America, 96 KY. L.J. 275, 281 n. 38 (2007-08).

158. See, e.g., Dandy v. Dandy, 234 So.2d 728, 730 (Fla. Dist. Ct. App. 1970).

159. See, e.g., Davidson v. Davidson, 151 N.W.2d 53, 55 (Wis. 1967) (for voidable marriage, action abates upon death of a party); Nunley v. Nunley, 210 A.2d 12, 14 (D.C. 1965) (same).

160. CAL. FAM. CODE $\$ 2250$ (West 2014); Del CODE ANN. tit. 13, $\$ 1506$ (b) (West 1975) (after death action permissible only if brought by either putative spouse or the legal representative of the alleged incapacitated party not more than 90 days after the petitioner learned of the incapacity); 750 Ill. Comp. Stat. Ann. 5/302(b)(1) (West 1999) (same as Delaware); Mont. STAT. AnN. § 40-1402(2) (West 2005) (action must be brought within one year of petitioner's knowledge of impaired party's condition); N.Y. DOM. REL. LAW $\$ 140$ (c) (McKinney 2014) (after death action permissible on the basis of mental illness if brought by an interested relative but not if brought by next friend); OHI REV. CODE $\S 3105.32$ (c) (Page 2003) (action for annulment abates upon death of either party); S.D. CODIFIED LAWS § 25-3-2 (2014); TEX. FAM. CODE ANN. $\$ 6.111$ (West 2013) (after death proceeding for idiot permissible during either party's lifetime; for lunatics (all those of unsound 
specifically address the right to pursue annulment after the death of a party, a court may interpret other provisions of the statute governing annulments to prohibit such an action.

\section{4. "Heartbalm Actions"}

What about "heartbalm actions"? Beginning in the early 1900s, courts became increasingly disinclined to permit recovery in tort for claims that emerged out of "tender matters of romantic or sexual emotion." 161 Claims such as alienation of affection, breach of promise, or criminal conversation fell into disfavor under the weight of criticism that such claims were "anachronistic," resulted in excessive and unwarranted damage verdicts, and were used to extort or blackmail a marriage that was no longer wanted. ${ }^{162}$ Underlying much of the criticism was also the implicit belief that community mores had changed. ${ }^{163}$ Thus, for example, a failure to progress from engagement to marriage no longer carried the stigma that previously may have warranted a breach of promise action. As a result, a number of states enacted what are commonly referred to as "anti-heartbalm statutes," which bar breach of promise and related actions and abolish the old common law claims. ${ }^{164}$ Interestingly,

the arguments that fueled the movement to abandon heartbalm torts were hardly consistent with the view that women were independent, competent people who did not need the law's protection. Instead, the main arguments in support of the antiheartbalm movement centered on women's alleged misuse of the torts to extort money from men, with newspaper articles calling plaintiffs in these cases "gold-diggers" and "blackmailers" who used the heartbalm torts as tools for extortion. ${ }^{165}$

Many laws surrounding marriage and divorce may appear paternalistic or stigmatizing, both to persons with mental disabilities and

\footnotetext{
mind except idiots)); CoLo. REv. STAT. ANN. $\$ 14-10-111$ (2)(a) (West 2014). See also In re Estate of Fuller, 862 P.2d 1037, 1038-39 (Colo. App. 1993) (holding that marriage could not be annulled after death of one of allegedly incapacitated spouses because marriage was voidable rather than void).

161. See, e.g., Jane E. Larson, "Women Understand So Little, They Call My Good Nature 'Deceit'": A Feminist Rethinking of Seduction, 93 Colum. L. REv. 374, 381-412 (1993).

162. See, e.g., Jeffrey D. Kobar, Heartbalm Statutes and Deceit Actions, 83 Mich. L. REV. 1770, $1770,1775-78(1985)$.

163. See, e.g., Jill Evans, In Search of Paternal Equity: A Father's Right to Pursue a Claim of Misrepresentation of Fertility, 36 LOY. U. CHI. L.J. 1045, 1066 (2005).

164. Id. at 1066-70.

165. Deana Pollard, Sex Torts, 91 MinN. L. REv. 769, 789 n.116 (2007).
} 
to women in general. The clear distinction between the two groups, which is acknowledged in the law, creates inequality and furthers stereotypes about the marginalized groups, painting them as incompetent in matters involving their personal decisions.

\section{STERILIZATION}

Our legal system further marginalized the rights of persons with mental disabilities by creating laws allowing for forced sterilization of "defective" individuals. ${ }^{166}$ The choice to reproduce was taken away from anyone whose genetics could lead to a socially undesirable child being born. ${ }^{167}$ Cases such as Buck v. Bell ${ }^{168}$ reinforced the acceptability of the eugenics movement, and further segregated the population of persons with mental disabilities.

\section{A. Buck v. Bell}

In 1927, in the course of a Supreme Court decision permitting the forced sterilization of a woman with a mental disability, Justice Oliver Wendell Holmes wrote famously, "[t]hree generations of imbeciles are enough." ${ }^{169}$ Fifty years later, the Court issued a series of decisions related to mental disability law, and legal scholars began examining previous decisions more carefully. ${ }^{170}$ In 1976, Robert Burgdorf compared Buck v. Bell to the "philosophical premises underlying Nazi atrocities." ${ }^{171}$ After this scathing analysis of the decision, more scholars and critics came forward, agreeing with Burgdorf that this decision was "an embarrassing example of bad law.", It2 It became clear that forced sterilization was no longer supported in the academic legal community.

The most important development in this area in recent years has been the publication of Professor Paul Lombardo's brilliant book, Three Generations, No Imbeciles: Eugenics, the Supreme Court, and Buck v.

166. See Karl A. Menninger, Proof of Qualification for Sterilization of a Person with a Mental Disability, 49 AM. JUR. PROOF OF FACTS 3D § 101, § 1 (2014).

167. See, e.g., Steven S. Spitz, The Norplant Debate: Birth Control or Woman Control?, 25 COLum. Hum. RTS. L. REV. 131, 135-36 (1993).

168. 274 U.S. 200 (1927).

169. Id. at 207.

170. See Perlin, supra note 9 , at 547.

171. Robert L. Burgdorf, Jr. \& Marcia Pearce Burgdorf, Wicked Witch is Almost Dead: Buck v. Bell and the Sterilization of Handicapped Persons, 50 TEMP. L. Q. 995, 996 (1976).

172. See, e.g., Paul Lombardo, Three Generations, No Imbeciles: Eugenics, the SUPREME COURT, AND BUCK V. BELL (2008). 
Bell. ${ }^{173}$ Three Generations, finally and definitely, utterly discredits Justice Holmes' "chilling epigram" 174 in his infamous "three generations" opinion. ${ }^{175}$ Professor Lombardo's work and other research of the past thirty years all demonstrate the utter lack of scientific basis for the conclusion that either Carrie Buck or any of her succeeding generations were "mentally defective" or "imbeciles." 176

\section{B. Misapplication of "Best Interests" Standard}

The jurisprudence on sterilization in the United States, Australia, England, and Canada makes clear that decisions are "routinely made on behalf of girls and women with disabilities by their parents and caregivers, ostensibly in their 'best interests,' without considering whether informed consent can be obtained." 177 In the United States, several courts have weighed state constitutional provisions along with their federal counterparts in cases involving petitions for involuntary sterilization of minors or incompetent persons, and have found both the right to be sterilized and the right to autonomy in sterilization decision making to be protected by such provisions. ${ }^{178}$

The New Jersey Supreme Court, for example, first recognized that, although a right to sterilization had not received express constitutional protection from the United States Supreme Court, several lower courts had found such a right. Drawing on its decision in In re Quinlan, ${ }^{179}$ the right to be sterilized was included in the privacy rights afforded by the

173. Id.

174. Perlin, supra note 9 , at 539

175. There are political implications of sterilization decision making as well. See, e.g., Yee-Fui Ng, Disability Rights v. Quality Birth Rhetoric: The Construction of Disability in China, LAWASIA J. 1, 1-2 (2012) (discussing implications of China's policy of "quality births," leading to the sterilization of couples with mental disabilities); Werner, supra note 3 , at 16-17 (discussing sociopolitical implications of sterilization decision making in Taiwan); Y.C. Chou \& Z.Y. Lu, Deciding About Sterilization: Perspectives from Women with an Intellectual Disability and Their Families in Taiwan, 55 J. INTELL. DISABILITY RES. 63, 64 (2011) (same).

176. See, e.g., Robert J. Cynkar, Buck v. Bell: "Felt Necessities" v. Fundamental Values?, 81 Colum. L. REV. 1418, 1455 (1981); Stephen J. Gould, Carrie Buck's Daughter, 2 Const. COMMENT. 331, 334 (1985).

177. Willene Holness, Informed Consent for Sterilisation of Women and Girls with Disabilities in the Light of the Convention on the Right of Persons with Disabilities, 27 AGENDA 35, 46 (2013).

178. For a comparative perspective, see generally L. Servais et al., Sterilisation of Intellectually Disabled Women, 19 EUROPEAN PSYCHIATRY 428 (2004) (discussing high rate of sterilization of such women in Belgium, and noting the correlation between sterilization rates and institutional residence).

179. 355 A.2d 647 (N.J. 1976), cert. denied, 429 U.S. 922 (1976). 
federal Constitution. ${ }^{180}$ Beyond this basis, the court specifically found that the right was also protected by the state constitution, and that "[the] governmental intrusion into privacy rights may require more persuasive showing of a public interest under our State Constitution than under the federal Constitution." 181

In one case, the California Supreme Court found that state legislation that absolutely forbade sterilization of persons under conservatorship deprived persons with developmental disabilities of their privacy rights under the state and federal constitutions. ${ }^{182}$ The court also found the right of a woman "to choose whether or not to bear a child and thus to control her social role and personal destiny" was a fundamental right under the same state constitutional provision, which could be restricted only by a compelling state interest. ${ }^{183}$

Other cases have discussed the legality of whether a circuit court can rule on the petition of a guardian seeking to have an adult with mental retardation sterilized. ${ }^{184}$ By way of example, In re Matter of Susan S. ${ }^{185}$ found that a trial court of general jurisdiction had, pursuant to state a constitution, broad parens patriae power over incompetent persons, enabling that court to act on a petition seeking sterilization. ${ }^{186}$ On the other hand, the Colorado Supreme Court held that there was no clear and convincing evidence to show that a woman with mental disabilities was unable to grant or withhold consent to sterilization, and the state constitutional law issue was thus not reached. ${ }^{187}$ In a later case, the Eighth Circuit found that, if proven, the allegations that state social service workers had compelled a mildly retarded woman to submit to a tubal ligation rose to the level of a due process violation. ${ }^{188}$

Sterilization, in some cases, may even be a "bargaining chip" as part of a plea arrangement. In a Louisiana decision, seventy-eight year-old Frank Tullier agreed to carry out his surgical castration that was part of an earlier plea deal for eventual release back to the community. ${ }^{189}$ In the

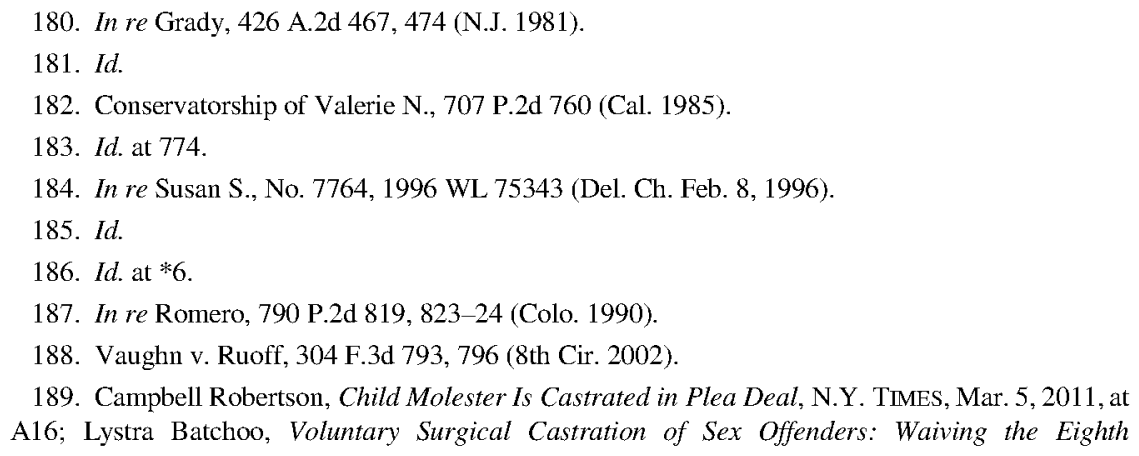


decision discussing Tullier's release, the trial judge in that case mandated that it was "time to give Caesar what is owed Caesar." 190

Professor Heather Ellis Cucolo has discussed the "sanitization of sex" among the cohort of offenders in civil commitment settings. ${ }^{191}$ In addition to sterilization, there has been a recent increase in the recommendation of chemical castration in sex offender cases. ${ }^{192}$ She observes that we sanitize through administering drugs to chemically castrate individuals, as well as performing actual castration. ${ }^{193}$ Although consent issues rarely arise in these cases, the question of duress needs to be considered when offenders are told that these medications and procedures are their only hope for freedom and eventual release to the community. Even with castration, offenders are often still not viewed as candidates for release. ${ }^{194}$

The fear of individuals with mental disabilities who have committed sex offenses is twofold: not only have they committed a particularly taboo offense, but there is the stigma and perception by society that, because of a mental illness, they are particularly sexually dangerous. Even the "sanitization" of their "out-of-control" sexual urges does not allow for their release. In an earlier article, one of the authors focused on how our fears of this population-fears stoked by,

the impact of media distortions on legislative policies, the lack of a factual basis for the public's obsessive fears (fears based on 'biased recall and unrealistic crime stereotypes'), the ways that such media distortion and public pressures affect judicial decision-making - [doom us] to endlessly play out a 'pathological' morality drama[,] ... in spite of the overwhelming empirical evidence that shows that the laws in question have little or no effect on sexual offending rates and

Amendment Protection from Cruel and Unusual Punishment, 72 BRoOK. L. REV. 689, 691-92 (2007).

190. See Robertson, supra note 189.

191. Heather Ellis Cucolo, Right to Sex in the Treatment and Civil Commitment of Sexually Violent Predators 41 (July 2007) (paper presented to the International Academy of Law and Mental Health Biennial Congress, Padua, Italy) (on file with authors).

192. John F. Stinneford, Incapacitation Through Maiming: Chemical Castration, The Eighth Amendment and Denial of Human Dignity, 3 U. ST. THOMAs L.J. 559, 577 (2006).

193. See Michael L. Perlin, “All His Sexless Patients”: Persons with Mental Disabilities and the Competence to Have Sex 38 (Apr. 2011) (paper presented to the Rocky Mountain Psychological Association), available at http://papers.ssrn.com/sol3/papers.cfm?abstract_id=1908733.

194. Linda E. Weinberger, Shoba Sreenivasan, Thomas Garrick \& Hadley Osran, The Impact of Surgical Castration on Sexual Recidivism Risk Among Sexually Violent Predatory Offenders, 33 J. AM. ACAD. PSYCHIATRY \& L. 16, 30 (2005). 
recidivism. ${ }^{195}$

These fears and this "morality drama" affect and infect all of the permutations of what we are discussing here.

\section{STATUTORY RAPE}

It is important to note that the case law and the theory that developed around issues of marriage, divorce, and sterilization have developed totally independent from the case law and theory that emerged in the area of statutory rape. A review of the relevant statutes and the case law reveals that not a single legislative committee that drafted any of these laws or the majority of a single appellate court that decided any of these cases ever gave the slightest thought to the issues that should be at the core of these inquiries. Only two concurring opinions in two obscure state cases even "get" any of the key issues. ${ }^{196}$ We now address these issues.

\section{A. Statutory Law}

A typical statute is that of Alaska: it is sexual assault in the third degree to engage in sexual contact with a person that the offender knows is "incapacitated" or "mentally incapable."197 Under state law, "incapacitated" means "temporarily incapable of appraising the nature of one's own conduct or physically unable to express unwillingness to act" ${ }^{198}$ (sounding as if meaning to describe someone who is seriously intoxicated or under the influence of drugs), and "mentally incapable" means "suffering from a mental disease or defect that renders the person incapable of understanding the nature or consequences of the person's conduct, including the potential for harm to that person." 199 In Alabama's similar statute, "mentally defective" is defined as meaning

195. Heather Ellis Cucolo \& Michael L. Perlin, "They're Planting Stories In the Press": The Impact of Media Distortions on Sex Offender Law and Policy, 3 U. DENV. CRIM. L. REV. 185, 222 (2013) (footnotes omitted); see also Heather Ellis Cucolo \& Michael L. Perlin, Preventing SexOffender Recidivism Through Therapeutic Jurisprudence Approaches and Specialized Community Integration, 22 TEMP. PoL. \& CIV. RTS. L. REV. 1 (2012).

196. For an article urging legislators to modify the ways that defendants with mental retardation may be charged with statutory rape, see Elizabeth Nevins-Saunders, Incomprehensible Crimes: Defendants with Mental Retardation Charged with Statutory Rape, 85 N.Y.U. L. REV. 1067 (2010). See generally infra text accompanying notes 218-21.

197. ALASKa STAT. ANN. § 11.41.425(a)(1)(A) \& (B) (West 2014).

198. Id. $\S 11.41 .470(2)$.

199. Id. § 11.41.470(4) (emphasis added). North Dakota's language is almost identical. See N. D. CENT. CODE $§ 12.1-20-03(1)$ (e) (West 2014). 
that "a person suffers from a mental disease or defect which renders him incapable of appraising the nature of his conduct." ${ }^{200}$ The New York laws are virtually identical. ${ }^{201}$

Arizona defines the term with a bit more detail:

The victim is incapable of consent by reason of mental disorder, mental defect, drugs, alcohol, sleep or any other similar impairment of cognition and such condition is known or should have reasonably been known to the defendant. For purposes of this subdivision, "mental defect" means the victim is unable to comprehend the distinctively sexual nature of the conduct or is incapable of understanding or exercising the right to refuse to engage in the conduct with another. ${ }^{202}$

\section{B. The Case Law}

An examination of the pertinent case law suggests that judges devote very little hard thought to the questions posed by these cases. Interestingly and somewhat surprisingly, the issue that emerges multiple times is a pair of evidentiary questions: what are the qualifications of an expert who testifies as to the victim's ability to consent, and when is such expert testimony needed at all? Most of the reported cases that look at the issues in any depth at all focus on this question. In a search of dozens of cases related to this subject, we found only two opinions, both concurrences, which seem to actually comprehend the scope of the issues involved. ${ }^{203}$ The cases that discussed these issues at all also seemed to deal with victims who were developmentally disabled, rather than mentally ill.

First, though, consider a 1950 case from Alabama: Stephenson v. State. ${ }^{204}$ Stephenson involved a case of sexual intercourse with a twentyseven year-old woman who became pregnant as a result of the rape (stunningly, named in the opinion). ${ }^{205}$ After noting that it was "lack of mental capacity, and not lack of moral quality and strength," ${ }^{206}$ here's how the appellate court constructed the issue:

\footnotetext{
200. ALASKA CODE ANN. § 13A-6-60(5) (LexisNexis 2014).

201. MCKINNEY'S PENAL LAW $\S \S 130.30(2), 130.00(5)$.

202. ARIZ. REV. STAT. ANN $\$ 13-1401(5)$ (b) (West 2014).

203. See State v. Soura, 796 P.2d 109, 116 (Idaho 1990); State v. Kingsley, 383 N.W.2d 828, 831

(N.D. 1986) discussed infra text accompanying notes 210-11 \& 220-22.

204. 48 So. 2d 255 (Ala. Ct. App. 1950).

205. $I d$. at 255 .

206. Id. at 256
} 
We know and hear of people whose mental powers to perceive and grasp are impaired along certain avenues of thought and yet whose perception is fairly normal in other respects. Lunacy implies a weakness or perversion of the mind, but not necessarily its destruction. Idiocy, even, is generally accepted to consist in only a defect or sterility of the intellectual powers. The degree, of course, varies. ${ }^{207}$

Mercifully, the modern cases mostly eschew this level of discourse.

Again, the bulk of the cases deal with issues of expertise, and all eventually affirmed convictions. A Washington case - after opining that "it has not even been shown that the psychological and psychiatric community is prepared to express an opinion on the issue [of whether expert testimony is necessary to establish incapacity]" ${ }^{, 08}$ - found that there was no reason to require expert testimony at all:

Evidence which establishes a rape victim's inability to understand the nature and consequences of sexual intercourse is not the kind of technical evidence which requires medical testimony to decipher. Unlike evidence of command delusions, or medical malpractice, or the functions of computers, a witness' comprehension of the basic consequences of his or her actions can be proved or disproved from his or her testimony and testimony as to behavior. ${ }^{209}$

There is no citation to any authority for this proposition.

A North Dakota case affirmed a conviction in which a social worker testified that the complainant was "“a child in a woman's body, and that... [s] he is not capable [of giving consent], [as she] would not understand all of the social implications of this relationship,",210 although it noted that "expert medical testimony would have established a stronger case." "211 A North Carolina case affirmed a conviction based on testimony of the victim's father that the complainant was "very limited... as far as being an adult"" and was "very easily sidetracked." ${ }^{212}$ A Massachusetts case affirmed a conviction in which a Division of Mental Retardation caseworker testified that the complainant "had the mental capacity of a nine year old child," without any predicate

207. Id. at 258 (emphasis added).

208. State v. Summers, 70 Wash. App. 424, 428, 853 P.2d 953, 956 (1993).

209. Id.

210. State v. Kingsley, 383 N.W.2d 828, 830 (N.D. 1986).

211. Id.

212. State v. Holley, 616 S.E.2d 30, No. COA04-1314, 2005 WL 1805036, at *2 (N.C. Ct. App. Aug. 2, 2005). 
evidence of any testing ever having been done on her, concluding further that the question of consent "did not require any expert testimony concerning the specific etiology of any limitations relevant to her consent." 213 And a Utah case affirmed a conviction based on the testimony of a "mental retardation professional" who was not licensed to diagnose mental retardation, reasoning that licensing was not "dispositive" of the expert's qualifications to offer an opinion on the victim's "ability to consent to a sexual relationship." 214

Other cases fail to consider the ambiguities and difficulties presented by the operative statutes. An Indiana case, by way of example, found, tautologically, that the "plain and ordinary meaning" of "mentally disabled or deficient"" in the state law was "subnormal intelligence or mental disease or defect." "215 A Washington case notes, without irony, that the complainant (whom the court found incompetent to consent to having sex) was married at the time. ${ }^{216}$ By way of contrast, a Georgia case specifically found that the fact that the victim had never been found to be legally incompetent did not mandate a conclusion that she was competent to engage in sexual activity. ${ }^{217}$ An Arizona case also considers whether the woman had "the capacity to understand the nature of her conduct," ${ }^{218}$ but fails to ever explicate what this means (that she might have a baby? That she might "feel good"? That she might have remorse?). The most bizarre of this set is an appellate case from California in which the court affirmed a conviction where the complainant was never sworn in as a witness but was permitted to answer questions - as to her age, her name, the spelling of her name-so that the fact-finders could "observe her behavior, her demeanor, [and] her actions." "219

Concurrences in two other cases demonstrate some grasp of the nuances of this difficult area of the law. In an Idaho case affirming a conviction (another case involving a married complainant), the majority quoted at length and with approval the trial court's observations that her

\footnotetext{
213. Commonwealth v. Fuller, 845 N.E.2d 434, 439 n.3 (Mass. App. Ct. 2006).

214. State v. Kelley, 1 P.3d 546, 550 (Utah 2000)

215. Douglas v. State, 484 N.E.2d 610, 613 (Ind. Ct. App. 1985).

216. State v. Ortega-Martinez, 124 Wash. 2d 702, 705, 881 P.2d 231, 239 (1994). Interestingly, this case otherwise carefully focuses on the difference between individuals who "may have a condition which permits them to have a knowledge of the basic mechanics of sexual intercourse, but no real understanding of either the encompassing nature of sexual intercourse or the consequences which may follow." Id. at 712,881 P.2d at 237.

217. Melton v. State, 639 S.E.2d 411, 416 (Ga. Ct. App. 2006).

218. State v. Johnson, 745 P.2d 81, 84 (Ariz. 1987).

219. People v. Morgan, 236 Cal. Rptr. 186, 189 (Cal. Ct. App. 1987).
} 
answers to questions were "slow and short," and that her facial expression consisted of a " "sagging jaw, mouth open.", ${ }^{220}$ Retorted the concurring opinion:

I do not understand why the majority takes the time to relate anecdotal evidence of the victim's appearance in court in order to support the district court's determination that the victim could not legally consent ... . If I did not know better, I would have thought that the day was long gone when a person's intelligence was judged by a person's appearance. ${ }^{221}$

In affirming the conviction, the majority had also gone out of its way to distinguish sex-within-marriage from sex-outside-of-marriage, pontificating that "non-marital sexual relations ... are not considered by society in a favorable light . . . because of the difficult consequences that may follow." 222

In another North Dakota case that affirmed a conviction, the concurring judges focused on the state's developmental disabilities rights law (the only such consideration of the rights of persons with disabilities in this entire universe of case law), noting:

It is well to bear in mind that there is no presumption of incompetence simply because a developmentally disabled person is receiving special services or living at a residence for the developmentally disabled [citing state law]. Nor is a developmentally disabled person deprived of the right to "interact" with members of the opposite sex. [citing state law]. I believe the State should, in cases like the instant one, present testimony of a medical expert on the subject of mental defect or mental disease and its effect on a particular individual's comprehension. The jury is entitled to at least that much, if not more assistance in reaching a verdict. ${ }^{223}$

Again, every one of these cases deals with an individual with a developmental or intellectual disability. The only on-point case involving a complainant with a mental illness was a Michigan appeal, in which the court rejected the defendant's argument that "a psychological expert or an in-depth examination of the [defendant's] mental health records would have been helpful," noting cursorily that "[i]t was established that [the] complainant was schizophrenic," and that, in

220. State v. Soura, 796 P.2d 109, 115 (Idaho 1990).

221. Id. at 116 (Bistline, J., specially concurring).

222. $I d$. at 114 (majority opinion).

223. State v. Kingsley, 383 N.W.2d 828, 831 (N.D. 1986) (Levine, J., specially concurring). 
conclusion, "there was nothing to suggest that more authoritative impeachment by an expert would have been of significant value."224

Interestingly, there has been some recent excellent and thoughtful scholarship on the global issues related to statutory rape, some arguing - in the context of consensual teenage $\operatorname{sex}^{225}$ - that criminal penalties rise to the level of cruel and unusual punishment under the Eighth Amendment. ${ }^{226}$ Yet, this has had virtually no impact on the case law in this area as it reflects the ongoing infantilization of women with mental disabilities. ${ }^{227}$

\section{OTHER APPROACHES: THE AMERICANS WITH DISABILITIES ACT ${ }^{228}$}

Some fifteen years ago, one of the authors speculated about the potential impact of the Americans with Disabilities Act on questions of patient sexuality. "Can hospital procedures-either written or unwritten-that prohibit all patients from meaningful, voluntary sexual interaction survive ADA-based challenges?"229 Congress's ADA findings specifically acknowledged how "overprotective rules and policies" discriminate invidiously against persons with mental disabilities. ${ }^{230}$ Certainly, many of the institutional rules banning sexual

224. People v. Campbell, No. 280424, 2008 WL 4958856, at *1 (Mich. Ct. App. Nov. 20, 2008).

225. Beyond the scope of this Article are issues that arise in cases involving teenage "sexting" (mailing or posting sexually explicit photographs of oneself). See generally JoAnne Sweeny, Sexting and Freedom of Expression: A Comparison Approach, 102 KY. L.J. 103 (2013-2014); Carissa Byrne Hessick \& Judith M. Stimson, Juveniles, Sex Offenses, and the Scope of Substantive Law, 46 TEx. TECH L. REv. 5 (2013); Julia Halloran McLaughlin, Exploring the First Amendment Rights of Teens in Relationship to Sexting and Censorship, 45 U. MICH. J.L. REFORM 315 (2012). In general, see Lucy Berliner, Sex Offenders: Policy and Practice, 92 Nw. U. L. REv. 1203, 1208 (1998) ("Sex offenders do not share a common set of psychological and behavioral characteristics.").

226. See, e.g., Meredith Cohen, No Child Lefi Behind Bars: The Need to Combat Cruel and Unusual Punishment of State Statutory Rape Laws, 16 J.L. \& POL'Y 717, 722-23, 742 (2008). For an inquiry into limitations on girls' capacity for autonomy and consent in sexual interactions, see Michelle Oberman, Turning Girls Into Women: Re-Evaluating Modern Statutory Rape Law, 8 DePaul J. Health CARE L. 109 (2004).

227. See, e.g., Perlin, supra note 9, at 537; Perlin, supra note 82, at 969; Benedet \& Grant, supra note 9, at 521-24; Sabatello, supra note 88, at 234 ("“W]omen with disabilities have often wrongly and unfairly been seen as asexual objects, persons without 'normal' familial and sexual needs, or a mere burden on society.").

228. On this question, see Perlin, supra note 82.

229. Id. at 967

230. On the ADA in the context of mental disability in general, see 3 MICHAEL L. PERLIN, MENTAL DisABILITY LAW: Civil AND CrIMINAL $\$ \$ 5$ A-2 et seq., at 145-222 (2d ed. 2002); Michael L. Perlin \& Heather Ellis Cucolo, Mental Disability law: Civil and Criminal 
contact flow from this discriminatory notion of over-protectionism.

The ADA's legislative history — as it applied to persons with mental disability-did focus specifically on questions of stereotyping and "reflects Congressional awareness of the pernicious danger of stereotyping behavior." ${ }^{231}$ It is likely that these policies flowed, in large part, from two contradictory stereotypes: one of infantilization (denying the reality that institutionalized persons with disabilities may retain the same sort of sexual urges, desires, and needs the rest of us have and generally upon which the rest of us act) and, paradoxically, one of demonization (expressing fear of their hypersexuality and the correlative need of protections and limitations to best stop them from acting on these primitive urges). How can these stereotypes be reconciled with the legislative history just considered?

To what extent do the courts see sex as a fundamental right? ? $^{232}$ Although the Supreme Court has never found sexual interaction per se to be a specifically protected right, it has found a fundamental right to privacy in a broad array of cases involving reproductive choice, ${ }^{233}$ contraception, ${ }^{234}$ marriage, ${ }^{235}$ and family relationships, ${ }^{236}$ and has recognized a fundamental right to be free, "except in very limited circumstances, from unwanted governmental intrusions into one's privacy." ${ }^{237}$ In the course of an opinion holding that a state may not condition the right to appeal from a decision terminating a parent's rights on his or her ability to pay certain filing fees, ${ }^{238}$ the Court stressed that "[c]hoices about marriage, family life, and the upbringing of children are among associational rights [that it] has ranked as 'of basic

$\$ \S 5 A-2$ et seq., at 14-101 (2013 Cum. Supp.).

231. Michael L. Perlin, The ADA and Persons with Mental Disabilities: Can Sanist Attitudes Be Undone?, 8 J.L. \& HEALTH 15, 25 (1993-94). On sexual stereotyping of women with mental disabilities, see generally Benedet \& Grant, supra note 9 .

232. On the significance of Lawrence v. Texas, 539 U.S. 558 (2003) (declaring unconstitutional state law criminalizing consensual sodomy), see Michael L. Perlin \& Naomi Weinstein, "Friend to the Martyr, a Friend to the Woman of Shame": Thinking About the Law, Shame and Humiliation $19-23$ (Jan. 17, 2014) (unpublished manuscript), available at http://papers.ssrn.com/sol3/papers. cfm?abstract_id=2380701.

233. Roe v. Wade, 410 U.S. 113, 153 (1973).

234. Griswold v. Connecticut, 381 U.S. 479, 485 (1965).

235. Loving v. Virginia, 388 U.S. 1, 12 (1967).

236. Moore v. City of East Cleveland, 431 U.S. 494, 503 (1977).

237. Stanley v. Georgia, 394 U.S. 557, 564 (1969). For a list of all areas in which the Court has recognized fundamental rights involving family life and personal autonomy (which may include sexual privacy), see Shawgo v. Spradlin, 701 F.2d 470, 482-83 (5th Cir. 1983), cert. denied, 464 U.S. 965, 971 (1983) (Brennan, J., dissenting from denial of certiorari).

238. M.L.B. v. S.L.J., 519 U.S. 102, 124 (1996). 
importance in our society,", 239 citing to, inter alia, Skinner v. Oklahoma ex rel. Williamson, ${ }^{240}$ a 1942 case finding a right to procreation. ${ }^{241}$

There is, in short, no compelling state interest to support a policy banning all voluntary sexual interaction in hospital facilities. Any presumption of incompetence that may be relied upon-either explicitly or implicitly - to support such a blanket proscription also fails to pass any sort of heightened scrutiny analysis, especially in light of the fundamentality of sexual experience as a constitutionally protected privacy right. This is not to suggest, of course, that hospital facilities are not free to impose reasonable restrictions on inpatient sexual activity. For a variety of clinical, administrative, and public safety reasons, carefully drawn limitations will pass ADA muster, as long as these policies are not based on stereotypes, allow for individualized decision making in individual cases, and authentically reflect a compelling state interest.

What has happened since the publication of the "Make Promises by the Hour" article in 1997 discussing the ADA and sexual autonomy? ? $^{242}$ The ADA has been invoked in a wide range of cases involving just about every aspect of family law and domestic relations: marriage, divorce, child custody, child dependency, and foster care. Although there is one case that considers these issues in the sterilization context-in Lake $v$. Arnold, ${ }^{243}$ the Third Circuit found that the plaintiff had stated a cause of action in case alleging that nonconsensual sterilization violated ADAby and large, the specific questions that are raised in this Article have not yet been addressed with any clarity or definitiveness.

\section{CONCLUSION}

In short, the issues discussed in this Article must be considered through multiple filters: through the filter of sanism, through the filter of international human rights, and through the filter of domestic antidiscrimination law. Each of these considerations must be contextualized with society's attitudes toward sexuality in general, and specifically, the bundle of attitudes that comes into play when we think of sexuality and persons with disabilities, and especially when that sexuality is not simply "vanilla" male-female intercourse. Our prejudices, our fears-

239. $I d$. at 116.

240. 316 U.S. 535 (1942).

241. $I$ d.

242. See Perlin, supra note 82.

243. 112 F.3d 682 (3d Cir. 1997). 
both spoken and unspoken-dominate the discourse (or, often, the lack of discourse) in this area of law and policy, and it is essential we confront this as we approach these issues.

These are our conclusions:

First, there is no unitary definition of competency in this area. Often, there are no definitions, and when definitions exist, they are often circular and contradictory.

Second, there is a whole range of issues to be considered in determining "sexual competency," but, as the cases we have discussed should make clear, these factors change from case to case, jurisdiction to jurisdiction, and substantive topic to substantive topic. However, where policies exist, they are often stigmatizing and marginalizing, and do not allow for the range of opportunities to engage in sexual activities afforded to those without mental disabilities.

Third, these substantive topics and the detrimental laws that do exist remain so under-discussed because we are still so astonishingly uncomfortable thinking about the questions at hand. We want to close our eyes to the reality that persons with mental disabilities are sexual beings, and want to close our eyes even more to the fact that their sexuality may be much more like "ours" than it is different.

Fourth, our current policies fly totally in the face of the "three V's" that Professor Amy Ronner articulated as the heart of therapeutic jurisprudence: voice, validation and voluntariness. ${ }^{24}$ They also are inconsistent with international human rights conventions, and perpetuate sanism.

Bob Dylan wrote, in Desolation Row, about the "sexless patients."245 Society wishes patients were sexless. They are not, and we need to deal with that reality. Notwithstanding the sexual revolution, the civil rights revolution, the gender-role revolution, the patients' rights revolution, and the human rights revolution, we remain moored in attitudes and prejudices of the past century (and, perhaps, the century before that) when we think about the issues addressed here. When the authors discuss them with friends and work colleagues, the responses, predictably, include embarrassment, titters, bad jokes, and a general sense of discomfort. We hope that, by writing this Article (and others dealing with similar issues), ${ }^{246}$ we can alter these predictable responses, and finally devote to this area of law and policy the attention it deserves.

\footnotetext{
244. Ronner, supra note 110 , at 627

245. Dylan, supra note 16

246. See, e.g., Perlin \& Lynch, supra note 2.
} 